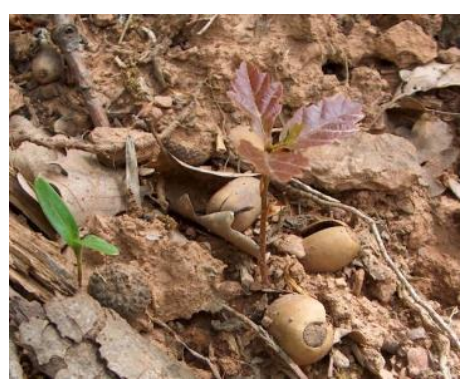

\section{ARTICLE INFO}

Citation:

Grossnickle SC, Ivetić V (2017)

Direct Seeding in Reforestation - A Field Performance Review.

Reforesta 4: 94-142.

DOI: https://dx.doi.org/10.21750/

REFOR.4.07.46

Editor: Jovana Devetaković, Serbia Received: 2017-11-30

Accepted: 2017-12-25

Published: 2017-12-30

This article was presented at IUFRO 125th Anniversary Congress - All Division 3 (Forest Operations Engineering and Management) Meeting: Session 121 - "Reforestation challenges: planting material, ecophysiology, biodiversity, climate change mitigation and adaptation, and disaster risk reduction"- 19-22 September, Freiburg, Germany.

\section{CrossMark}

Copyright: () 2017 Grossnickle Steven, Ivetić Vladan. This work is licensed under a Creative Commons Attribution 4.0 International Public License.

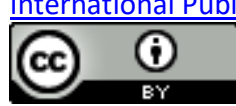

\title{
Direct Seeding in Reforestation - A Field Performance Review
}

\author{
Steven C Grossnickle ${ }^{1 凶}$, Vladan Ivetić ${ }^{2}$ \\ ${ }^{1}$ NurseryToForest Solutions \\ ${ }^{2}$ University of Belgrade - Faculty of Forestry \\ sgrossnickle@shaw.ca
}

\begin{abstract}
Direct seeding has been considered a forest restoration option for centuries. Over the past half century, the use of this practice has declined in developed countries as forest regeneration programs have advanced with the production of quality seedlings that can successfully establish restoration sites. Direct seeding is being reconsidered as a restoration option as the potential size of the worldwide forest restoration program has grown because of massive deforestation in third-world nations and due to global climate change. This review examines direct seeding from a number of perspectives. First, merits of using this practice in restoration programs are defined. Major merits of this option are that it can be done quickly, over hard to reach and large disturbed areas, and at a relatively low cost. Second, current research findings from restoration programs are discussed. The major finding is that seedling establishment rates are low (i.e. typically around $20 \%$ of seeds planted) due to site conditions, seed predation and vegetation competition, and field performance (i.e. survival and growth) is lower than planted seedlings. Third, operational practices for the application in restoration programs are reviewed. To successfully conduct direct seeding programs practitioners need to consider seedbed receptivity, seed distribution and seeding rate. Fourth, potential new practices are presented. Some of these new practices attempt to create a more effective means to disperse seed across the site, minimize seed predation or create a more favorable microsite environment. This review provides a synthesis of what is known about direct seeding, thereby allowing practitioners to make a rational decision of whether to apply this practice towards their forest restoration program.
\end{abstract}

\section{Keywords}

Direct Seeding; Reforestation; Forest Restoration; Seedling Establishment

\section{Contents}

1

2

3
Introduction

Merits of Direct Seeding as a Reforestation Option

2.1 Ecological

2.2 Biological - Root System Form

2.3 Economic

2.4 Operational

Current Direct Seeding Research

3.1 Conversion Rates

3.2 Factors Affecting Conversion Rates 
4 Direct Seeding versus Seedling Comparison

5 Operational Direct Seeding Practices

5.1 Reasons for the Limited Use of Direct Seeding

5.2 Direct Seeding - Recommended Seeding Rates

6 Potential Alternative Direct Seeding Practices

7 Conclusions

8 References

\section{Introduction}

The use of direct seeding with tree species has been an ongoing silvicultural practice in forest restoration programs for centuries. The first references discussing the application of direct seeding, as a reforestation practice, goes back to the $14^{\text {th }}$ century (cited by Willoughby et al. 2004). Direct seeding became a viable option during sustainable forestry programs in the $19^{\text {th }}$ century (reviewed by du Cros et al. 2004; Chick 2004; Ammer and Mosandl 2007). In fact, many methods discussed by Toumey (1916) (i.e. broadcast or drilled seeding in strip, line, hole or spot distribution patterns) are still considered standard practices today. Prior to the development of large-scale nursery programs to produce seedlings, direct seeding or partial seeding (i.e. the combination of direct seeding and leave-seed trees) were considered the 'best practice' for forest regeneration programs to reestablish a forest stand (Smith 1962).

Recently, there is an increasing interest in the use of direct seeding as an alternative to seedling planting. This is because the amount of forest restoration required worldwide is overwhelming. The last Forest Resources Assessment (FAO 2015) reported a global net forest loss of $3.3 \times 10^{6}$ ha year $^{-1}$ from 2010 to 2015 . This has resulted in the need to restore up to two billion hectares of forest sites worldwide (Minnemayer et al. 2011). Forest losses over the past 25 years have been highest in third-world nations (Sloan and Sayer 2015) and recently, the UN declared the need to restore forest to 350 million hectares of degraded land by 2030 to tackle climate change (United Nations 2014). Thus, low cost options are required to meet the size of this worldwide restoration program; such as direct seeding (Fischer et al. 2016) or natural regeneration (Uriarte and Chazdon 2016). There is a necessity to consider this practice as an option where the availability of seedlings is limited to address this very large forest restoration requirement and to provide a low cost option to shape degraded landscapes with desired tree species that creates a biodiverse forest ecosystem.

There have been several reviews on direct seeding of regional character (Douglas et al. 2007 - pastoral land in New Zealand; Schmidt 2008 - tropical forests; Peppin et al. 2010 - post-fire in western US; Pandey and Prakash 2014 - tropical dry forests), focused on few species (Dey and Buchanan 1995; Farlee 2013), focused on one perspective (Ceccon et al. 2016 - meta-analysis), or from an ecological perspective primarily examining tropical forest species (Ruiz-Jaen and Aide 2005; Pamela and Laurance 2015). This review contributes to the discussion by examining the field performance of direct seeding in forest restoration programs from a number of perspectives. The objective of this review is fivefold: 1 ) to examine the merits of direct seeding, 2) explore current research findings from a biological perspective across temperate and tropical forest species, 3) to evaluate responses to operational silvicultural practices, 4) to examine potential new application practices, and 5) to provide a synthesis of what is currently known about direct seeding practices so 
practitioners can make rational decisions on whether to apply this practice in their forest restoration program.

\section{Merits of Direct Seeding as a Reforestation Option}

\subsection{Ecological}

Under certain conditions there is a shift in the objective of establishing a new forest to a more ecological approach (species mixture, close to nature appearance and ecological based management). This approach has been defined as ecological restoration which "... is an intentional activity that initiates or accelerates recovery of an ecosystem with respect to health, integrity and sustainability." (SER 2002). Facing ambitious plans for forest restoration at global level, it is imperative to use the most suitable establishment technique directed at both ecological and economic aspects of the process. Forest restoration can restore many ecosystem functions and recover many components of the original biodiversity (Chazdon 2008). Thus direct seeding is suitable for ecological restoration with multiple species because it is easier to create species mixtures compared to planting (Schmidt 2008; Pandey and Prakash 2014), which have greater diversity at higher plant densities and are less expensive to implement than traditional seedling planting techniques.

Direct seeding, along with cover crops and/or nurse trees, has been considered a viable alternative to achieve a more "close-to-nature" silviculture option for site restoration (Madsen et al. 2016). In a review of projects in Brazil direct seeding with many species provided better species diversity in many site restoration programs compared with "passive restoration" (Brancalion et al. 2016). For example in a restoration project in the Brazilian dry forest, direct seeding or planting of seedlings increased the species richness compared to natural regeneration (Figure $1 \mathrm{~A}$ ). In other examples, direct seeding and planting of sites with multiple species initiated in the development of complex Amazonian forest ecosystem (Parrotta and Knowles 1999 and 2001) and the establishment of a mixture of Acacia species (and other genera) as potential hosts for Santalum spicatum (Woodal and Robinson 2002). In another Brazillian restoration project (Campos-Filho et al. 2014), a mixture called muvuca, consisting of native trees $\left(200,000\right.$ seeds $\left.\mathrm{ha}^{-1}\right)$, annual and subperennial legumes $\left(100,000\right.$ seeds ha $\left.^{-1}\right)$, and sand, was direct seeded by common agricultural machinery at the rate of $60 \mathrm{~kg} \mathrm{ha}^{-1}$. This approach results in a multilayer vegetation complex, and six years after seeding a mean density of 7,250 trees ha- ${ }^{-1}$, compared to 1,666 trees ha ${ }^{-1}$ in a seedling planting program. However, these very high direct seeding rates are required because tree seedling establishment rates are low (ranging from 1\% to 16\%) (CamposFilho et al. 2014); which are comparable to or lower than establishment rates reported for other tropical species (Table 2a). These examples support the view that successful direct seeding (sans planting) is a restoration strategy to restore biodiversity of degraded tropical forests (Lamb et al. 2005). Direct seeding is considered a viable option in ecological orientated restoration programs because, compared to natural regeneration, it allows for greater control of species composition and stocking levels on restored sites (Stanturf et al. 2014).

Direct seeding, like the planting of seedlings, has the potential to initiate a mixed structure stand. For example, it can create variable seed distribution (Figure 1B) and a wide size range of established seedlings (Figure 1C), to create non-uniform forest 
stands. In certain cases the creation of complex, rather than uniform, forest stands with diversity of stand structures is considered a desirable pathway to ecological forest restoration (Oliver et al. 2016).
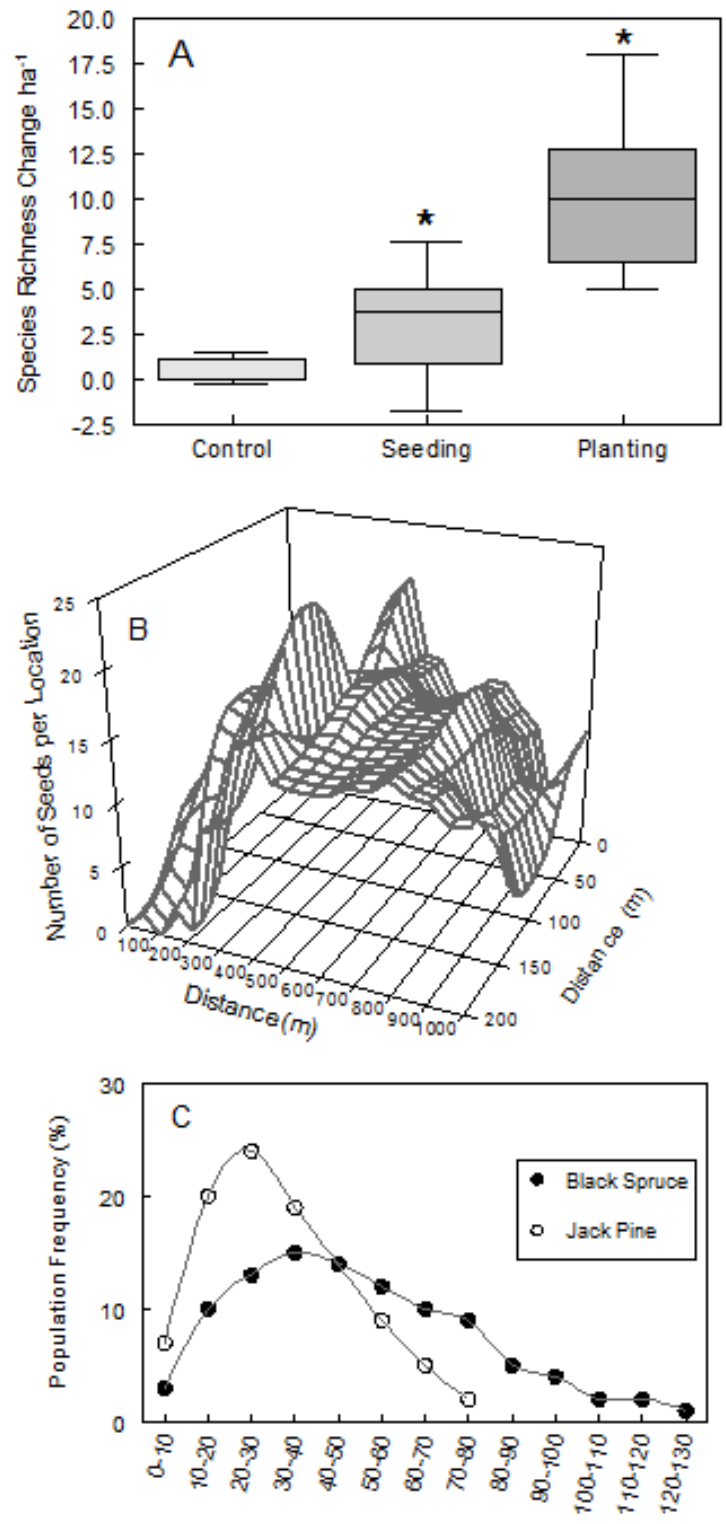

Height Class (cm)

Figure 1. A) Changes of species richness between initial and final measurements $\left({ }^{*}\right.$ indicates treatments are significantly different based on a Tukey test $p=0.05$ ) for restoration treatments direct seeding and seedling planting in relation to a control site (average initial species richness of 18 with a range of 11-26) in the Brazilian Deciduous forest region (adapted from Sampaio et al. 2007), B) Distribution of seeds collected from an aerial seeded program for Enterolobium cyclocarpum across a restoration site (adapted from Garcia Cuevas et al. 2010), and C) Seedling height frequency distribution of direct seed sites for Picea mariana after ten years (adapted from Groot 1996) and Pinus banksiana) after three years (adapted from Foreman 1997). 
Enrichment seeding of late successional species in established forests is considered a potential restoration strategy to increase species diversity at a low cost (Holl and Aide 2011). Direct seeding of late successional hardwood species under conifer plantations to create more diverse forest stands has had modest success because seedling establishment rates are low (i.e. 13\%) (Balandier and Prévosto 2016) or growth is less than planted seedlings (Ammer and Mosandl 2007). Active methods of ecological restoration require that site-adapted seed material be sown in the outplanting window when site environmental conditions are suitable for seedling establishment (Stanturf 2016). Thus issues related to successful stand establishment still need to be considered (see Direct Seeding Field Performance section) because not all direct seeding programs are successful (Peppin et al. 2010), making this a uncertain ecological restoration option in late successional forests.

\subsection{Biological - Root System Form}

Direct seeding is perceived to produce field-grown plants that have a more natural root system compared to planted seedlings (Ammer and Mosandl 2007). Trials found that seeded-in-place root systems typically have an open and unrestricted pattern with either tap roots or lateral roots radiating from the root collar (Little and Somes 1964; Sutton 1969; Long 1978; Preisig et al. 1979; Van Eerden 1982). However, this pattern is not universal because seedlings originating from seed can also have poorly formed root systems (Harrington et al. 1989). Bareroot and container-grown seedlings initially take on a different root form because these stocktypes' root form is, in part, dictated by nursery cultural and planting practices (reviewed by Grossnickle and El-Kassaby 2016).

Differences in root form between direct seeded seedlings and planted seedlings are still considered an issue in developing current restoration programs (e.g. Fischer et al. 2016). This concern stems from the fact that a number of studies reported newly established planted seedlings/saplings had shoot system stability issues (Nichols and Alm 1983; Halter et al. 1993; Balisky et al. 1995; Wennström et al. 1999). However, this concern is not always apparent. For example, belowground root development patterns of Pinus radiata did not differ between direct seeded and planted seedlings, with the potential for toppling related to shoot biomass allocation (Waston and Thombleson 2002). Even though there is a planted seedling stocktype effect on long-term root development patterns, inherent species characteristics and site environmental and soil physical factors also shape root system form as seedlings/saplings grow into an established forest stand (Sutton 1969). Root distribution, tree stability and stem straightness of planted seedlings can develop over time a similar form of trees regenerated from seed (Grossnickle and El-Kassaby 2016).

\subsection{Economic}

Direct seeding is considered a viable regeneration option because it is cheaper than planting seedlings (Smith 1962; Jõgiste et al. 2016). Direct seeding avoids all costs involved in planting seedlings (i.e. reduced labor, less equipment, no nursery and limited handling costs, and minimal operational plans). If one just defines reforestation success as 'putting the plant material for the next forest stand into the ground', then direct seeding costs are considerably lower than planting seedlings. 
Table 1. Cost comparison between direct seeding and planting seedlings for various forest restoration programs. The cost comparison ratios between direct seeding and either container-grown or bareroot seedlings was calculated for a density of 2,500 seedlings ha-1.

\begin{tabular}{|c|c|c|c|c|c|c|c|c|c|}
\hline \multirow[t]{3}{*}{ Species } & \multicolumn{4}{|c|}{ Prices ha-1 } & \multirow{2}{*}{\multicolumn{4}{|c|}{ RATIO $^{(3}$}} & \multirow[t]{3}{*}{ SOURCE } \\
\hline & & Cont & iner & & & & & & \\
\hline & 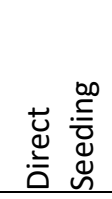 & 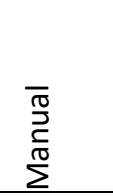 & 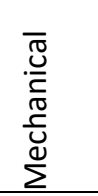 & 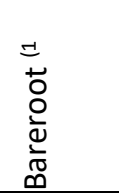 & 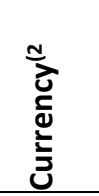 & 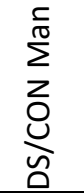 & 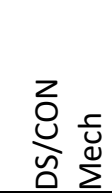 & $\frac{\stackrel{c}{0}}{\tilde{\omega}}$ & \\
\hline $\begin{array}{l}\text { Multiple species in } \\
\text { Australia }\end{array}$ & 1,121 & 6,913 & 5,420 & & AUS & $16 \%$ & $21 \%$ & & Summers et al. 2015 \\
\hline Pinus contorta & 365 & & & 1,280 & CAN & & & $28 \%$ & $\begin{array}{l}\text { Caldicott } 1989 \text { (converted to } \\
2500 \text { seedlings per ha) }\end{array}$ \\
\hline Pinus contorta & 249 & & & 772 & US & & & $32 \%$ & Sullivan and Sullivan 1984 \\
\hline $\begin{array}{l}\text { Pseudotsuga } \\
\text { menziesii }\end{array}$ & 303 & & & 772 & US & & & $39 \%$ & \\
\hline Pinus sylvestris & 450 & 1,000 & & & Euro & $45 \%$ & & & Helenius 2016 \\
\hline Quercus robur & 1,375 & & & 3,000 & Euro & & & $46 \%$ & Madsen and Löf 2005 \\
\hline Quercus sp. & 845 & 1,200 & & & Euro & $70 \%$ & & & $\begin{array}{l}\text { González-Rodríguez et al. } \\
2011\end{array}$ \\
\hline Betula sp. & 245 & & & 1,415 & UK & & & $17 \%$ & Willoughby et al. 2007 \\
\hline $\begin{array}{l}\text { Five species in } \\
\text { Costa Rica }\end{array}$ & 351 & & & 3,737 & AUS & & & $9 \%$ & $\begin{array}{l}\text { Cole et al. } 2011 \text { (converted to } \\
2500 \text { seedlings per ha) }\end{array}$ \\
\hline $\begin{array}{l}\text { Five species in } \\
\text { Brasil }\end{array}$ & 830 & & & 1,850 & US & & & $45 \%$ & Engel and Parrotta 2001 \\
\hline $\begin{array}{l}\text { New Zealand native } \\
\text { species }\end{array}$ & 9,610 & & & 18,745 & NZ & & & $51 \%$ & Douglas et al. 2007 \\
\hline Quercus sp. & 64 & & & 150 & US & & & $42 \%$ & Bullard et al. 1992 \\
\hline $\begin{array}{l}\text { Fagus sylvatica and } \\
\text { Abies alba }\end{array}$ & 900 & & & 6,600 & US & & & $14 \%$ & Baumhauer et al. 2005 \\
\hline Fagus sylvatica & 700 & & & 3,750 & Euro & & & $19 \%$ & Madsen et al. 2006 \\
\hline Fagus sylvatica & 2,000 & & & 7,000 & Euro & & & $28 \%$ & Birkedal et al. 2006 \\
\hline Pinus kesiya & 339 & & & 2,050 & $\mathrm{PhP}$ & & & $16 \%$ & Noble 1985 \\
\hline Pinus banksiana & 210 & 717 & & & US & $29 \%$ & & & Adams et al. 2005 \\
\hline Picea mariana & 216 & 780 & & & US & $28 \%$ & & & Adams et al. 2005 \\
\hline AVERAGE RATIO & & & & & & $38 \%$ & $21 \%$ & $30 \%$ & \\
\hline
\end{tabular}

1) Stocktype trial information was defined as bareroot seedlings when there was clear definition of stocktype type.

2) Currency: Australian dollar (AUS), United States dollar (US), Canadian dollar (CAN), Euro (EU), United Kingdom pound (UK), New Zealand dollar (NZ)

3) DS - direct seeding, Cman - manual planting of container seedlings, Cmech - mechanized planting of container seedlings.

A review of studies comparing costs between direct seeding and planting found the average cost of direct seeding per hectare was 30\% to $38 \%$ (ranging from $9 \%$ to $51 \%$ ) of planting costs for planting of bareroot and container-grown seedlings (Table 1); with the cost ratio, strongly dependent on seed price and seeding rate. Other economic analyses have also found that it can cost from 40\% (Bullard et al. 1992; Duryea 1992; Campos-Filho et al. 2014) to 50\% (Schultz 1997; Thomson 2007; Matute and Mitchell 2015) the cost of planting seedlings. Direct seeding was up to 29 times more cost effective than planting container stock when considering base costs, though it resulted 
in lower establishment success compared to container-grown seedlings (Palmerlee and Young 2010). However, in some cases high seed price and seeding rate, result in direct seeding costing more than planting (i.e. seeding of 100,000 acorns ha ${ }^{-1}$ costs $175 \%$ of the price for planting 2,500 oak seedlings ha ${ }^{-1}-$ Willoughby et al. 2004).

However, successful forest restoration is a comprehensive process. During the initial stages of forest regeneration, a series of intensive nursery or seed preparation, and silviculture practices are required to ensure successful seedling establishment (Gladstone and Ledig 1990; Grossnickle 2000). Ultimately, any determination of forest regeneration success needs to consider all costs that are required to achieve a fully established forest stand. These costs include 1) Species and genetic source selection, 2) Seed collecting and processing, 3) Site modifications and seedbed preparation, 4) Seeding, 5) Vegetation and predation control, and 6) Re-seeding and thinning. Potential failure can occur from direct seeding if preparation of the site and the protection of newly established seedlings are not consider part of a comprehensive plan (Toumey 1916; Balandier and Prévosto 2016).

\subsection{Operational}

Direct seeding needs to be compared to conventional seedling planting programs to determine when it is a viable operational option. The following is a list of operational reasons for using direct seeding in a restoration program (Toumey 1916; Smith 1962; Herman 1978; Barnett and Baker 1991; Owston et al. 1992; Fleming et al. 2001; Ochsner 2001; Schmidt 2008; Ezell 2012; Barnett 2014).

- Rapid reforestation of large areas which result from wildfire or other natural disasters.

- Rapid restoration after a disturbance to give the desired tree species an opportunity to reestablish the site before development of competing vegetation.

- Provides a 'shortcut' alternative to implement the planting step of a restoration program.

- Planting of remote or inaccessible sites or sites with rocky soils making it difficult to plant seedlings.

- A viable restoration option where there is a limited availability of bareroot or container-grown seedlings.

- Enrichment planting in secondary forests.

- Restoration of disturbed areas where natural regeneration is not adequate.

- Afforestation option for large abandoned agricultural sites and mine reclamation projects.

- Application in agroforestry situations for rapid control of site resources away from weed species and directed towards the agricultural crop and tree species.

- Use on low-productive or disturbed sites where the cost of planting operations is not economically feasible.

- Use in low-budget restoration programs addressing conservation and recovery of forest ecosystems.

Direct seeding is a 'more simplified regeneration practice' because it avoids relatively complicated nursery, handling and planting phases. However, direct seeding requires substantial quantities of seeds to sufficiently stock the field sites (see Recommended Seeding Rates section). Direct seeding requires less labour, and can be 
mechanized (e.g. drilling and aerial seeding). This simplified silvicultural operation could be critical for restoring up to two billion hectares of forest sites worldwide (Minnemayer et al. 2011).

Silvicultural practices that are part of an overall restoration program (e.g. vegetation control and surveys to define stand establishment success) are affected by whether the site is established via direct seedling or seedling planting. During the establishment phase, directly seeded seedlings are much smaller compared to planted seedlings (see - Direct Seeding versus Seedling Comparison section), which complicates vegetation control (see - Competitive Vegetation section). In addition, direct seeding creates an irregular pattern of seedlings, thereby limiting systematic mechanized vegetation control. Two or three assessments of establishment success are typically required after direct seeding because of delayed seedling establishment (Barnett 2014). Thus, silvicultural practices need to be modified to integrate a direct seeding program into the overall forest regeneration process.

\section{Current Direct Seeding Research}

The following discussion provides a review of 75 direct seeding trials from the past 25 years. This represents a comprehensive, though not exhaustive, examination of recently published literature for tropical (Table 2a), temperate hardwood (Table $2 b$ ) and conifer (Table 2c) tree species and describing major trends.

\subsection{Conversion Rates}

Germination Rate - The overall average germination rate for direct seeding was $44 \%$ and ranged from $9 \%$ to $92 \%$. The average germination rate was $38 \%$ for tropical species, $47 \%$ for temperate hardwoods and $46 \%$ for temperate conifers.

Establishment Rate - (survival rate after at least one growing season per / total number of seeds planted) - The establishment rate across all studies was $21 \%$ ranging from $0 \%$ to $92 \%$. The average establishment rate was $17 \%$ for tropical species, $28 \%$ for temperate hardwoods and $16 \%$ for temperate conifers.

These findings show that, in general, direct seeding programs result in a low rate of initial stand establishment. Other reviews also have shown low seedling establishment rates with direct seeding on restoration sites (Pamela and Laurance 2015; Ceccon et al. 2016). Historically, reasons for low establishment rates are timing of seeding (Wendel 1971; Ledgard 1976), planting practices (Wendel 1971), microsite environment (Show 1924; Wahlenberg 1925; Wendel 1971; Ledgard 1976), competitive vegetation (Fraser 1981) and seed predation (Show 1924; Wahlenberg 1925). These factors interact together to result in low seedling establishment rates. For example, Lawrence and Rediske (1962) found that seed losses occurred throughout the first year, due to various factors, as seeds go through the germination process and attempt to grow into an established seedling (Figure 2). 


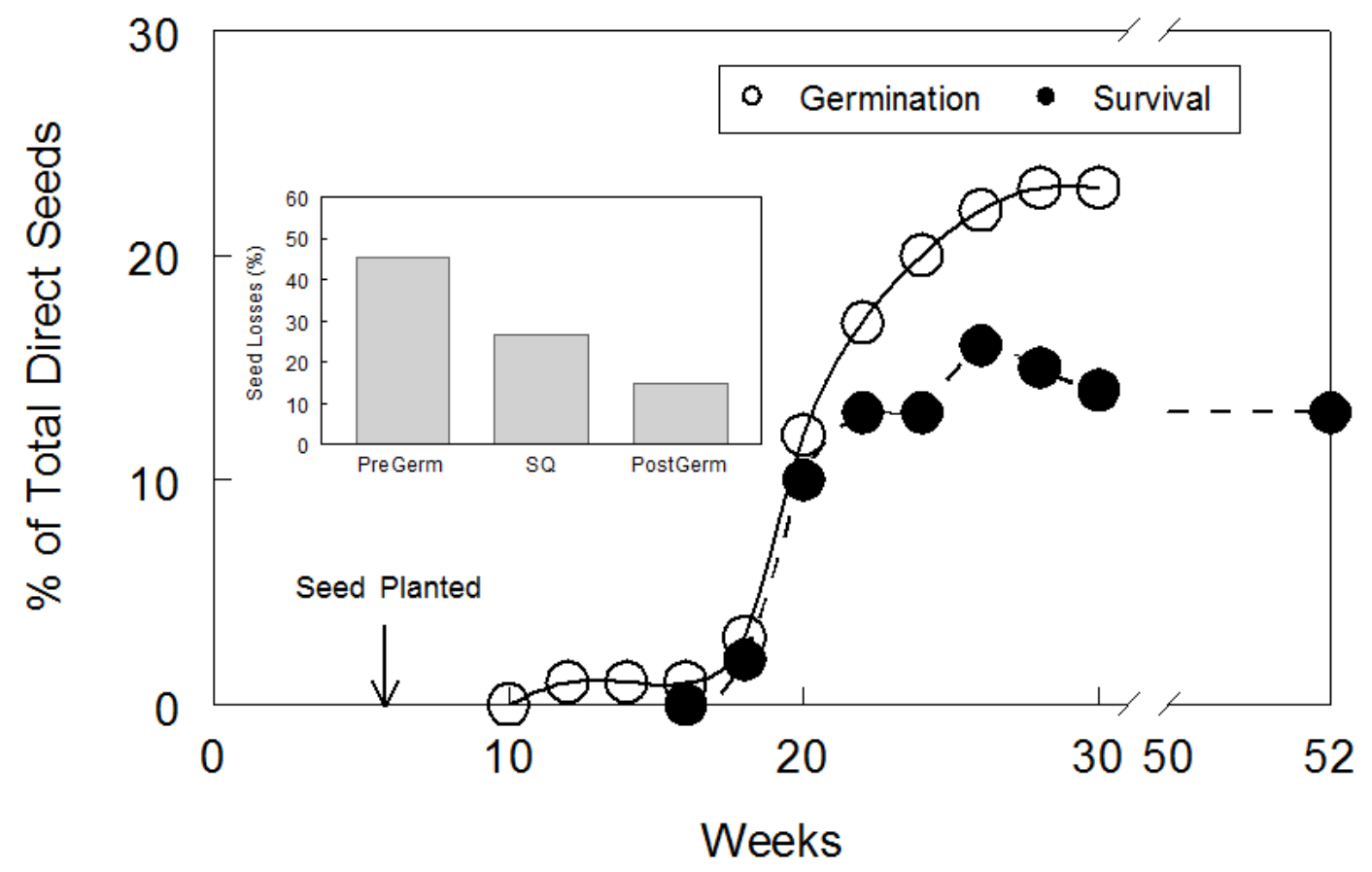

Figure 2. Germination and survival of Pseudotsuga menziesii var. menziesii seedlings in a direct seeding trial on a scarified reforestation site during one year. Insert figure shows where seed losses occurred during the trial: pre germination

(PreGerm -losses primarily from molds, insects, rodents and birds), seed quality (SQ -due to empty, moldy or quality seed that did not germinate), or post germination (PostGerm -due to fungi or environment [frost or desiccation]) (adapted from Lawrence and Rediske 1962).

To achieve a successful direct seeding program, several factors must be considered. Toumey (1916) listed these factors as 1) tree species and seed quality, 2) timing of seeding, 3 ) depth of covering (i.e. planting practices), 4) soil conditions (i.e. microsite environment), 5) vegetative cover, and 6) seed predation. As noted above, these are the same factors associated with reduced conversion rates. Along with the quantity of seed sown (see Direct Seedling - Recommended Seeding Rates section), some combination of these factors determine whether direct seeded material successfully goes through the three main stages in the establishment of direct seedling; which are germination, establishment during the first growing season, and survival and growth over the first couple of years. In current published work these controlling factors are still important for direct seeding success as discussed in the following sections. 
Table 2a. Direct seeding field performance of tropical forest species.

\begin{tabular}{|c|c|c|c|c|}
\hline $\begin{array}{l}\text { ñ } \\
\text { D } \\
\frac{n}{D} .\end{array}$ & 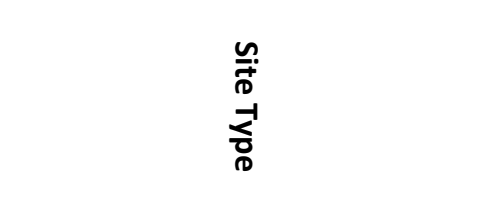 & 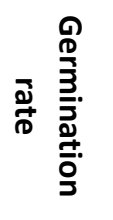 & 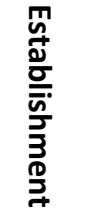 & $\begin{array}{l}\text { D } \\
\mathbb{D} \\
\mathbb{D} \\
\frac{D}{D} \\
D \\
D\end{array}$ \\
\hline Borneo rain forest species Ficus stupenda & Reforestation & & $0 \%$ & Laman 1995 \\
\hline \multirow[t]{2}{*}{ Pioneer rainforest species Alphitonia petriei } & Reforestation & & $7 \%$ & Sun et al. 1995 \\
\hline & Reforestation - Weed Control & & $27 \%$ & \\
\hline \multirow[t]{2}{*}{9 native species to Puerto Rico forests } & Afforestation & $32 \%$ & $18 \%$ & Zimmerman et al. \\
\hline & Reforestation site - Weed Control & $17 \%$ & $10 \%$ & 2000 \\
\hline 5 native tree species to the Amazon Basin & Reforestation & $10 \%$ & $5 \%$ & $\begin{array}{l}\text { Engel and Parrotta } \\
2001\end{array}$ \\
\hline 6 native tree species to Hawaii & Reforestation - Multiple & & $3 \%$ & Cabin et al. 2002 \\
\hline \multirow[t]{4}{*}{11 native tree species to the Amazon Basin } & Bare Soil & & $33 \%$ & Camargo et al. \\
\hline & Pasture & & $23 \%$ & 2002 \\
\hline & Secondary Forest & & $15 \%$ & \\
\hline & Mature Forest & & $12 \%$ & \\
\hline 20 native tree species to Panama Tropical & Reforestation -Shaded & & $19 \%$ & Hooper et al. 2002 \\
\hline Forests & Reforestation - Mowed/Sun & & $9 \%$ & \\
\hline 3 native Malaysian Tropical forest species & Reforestation & & $5 \%$ & $\begin{array}{l}\text { Howlett and } \\
\text { Davidson } 2003\end{array}$ \\
\hline Swietenia macrophylla & $\begin{array}{l}\text { Reforestation - Buried } \\
\text { Reforestation - Surface }\end{array}$ & & $\begin{array}{l}9 \% \\
4 \%\end{array}$ & $\begin{array}{l}\text { Negreros-Castillo et } \\
\text { al. } 2003\end{array}$ \\
\hline Australian Tropical Forest Species & $\begin{array}{l}\text { Reforestation - Broadcast } \\
\text { Reforestation - Buried }\end{array}$ & & $\begin{array}{c}4 \% \\
28 \%\end{array}$ & Doust et al. 2006 \\
\hline Eight Indian tropical dry forest specis & Afforestation & & $30 \%$ & $\begin{array}{l}\text { Singh and Singh } \\
2006\end{array}$ \\
\hline \multicolumn{5}{|l|}{ Ecosystem } \\
\hline Enterolobium cyclocarpum & Reforestation & & $22 \%$ & $\begin{array}{l}\text { Garcia Cuevas et al. } \\
2009\end{array}$ \\
\hline Three tree species in the semi-evergreen & Recently abandoned (<5 years) & & $7 \%$ & Bonilla-Moheno \\
\hline \multirow[t]{2}{*}{ forest - Yucatan Peninsula, Mexico } & $\begin{array}{l}\text { Young successional forest (8-15 } \\
\text { years) }\end{array}$ & & $16 \%$ & and Holl 2010 \\
\hline & Established forest (>50 years) & & $21 \%$ & \\
\hline \multirow[t]{2}{*}{ Keteleeria evelyniana } & Afforestation - Buried & & $42 \%$ & Sovu et al. 2010 \\
\hline & Afforestation - Broadcast & & $13 \%$ & \\
\hline Schima wallichii & & & $14 \%$ & \\
\hline Pinus kesiya & & & $38 \%$ & \\
\hline \multirow[t]{3}{*}{ Tropical montane forest } & Tree plantation & $43 \%$ & $32 \%$ & Cole et al. 2011 \\
\hline & Pasture & $43 \%$ & $18 \%$ & \\
\hline & Secondary forest & $43 \%$ & $19 \%$ & \\
\hline \multirow{3}{*}{$\begin{array}{l}\text { Seeds of } 19 \text { indigenous lowland tropical forest } \\
\text { tree species from Thailand }\end{array}$} & Seed Size - Small & & $5 \%$ & Tunjai and Elliott \\
\hline & Seeds Size - Medium & & $18 \%$ & 2011 \\
\hline & Seed Size - Large & & $40 \%$ & \\
\hline \multirow[t]{2}{*}{ Indigenous tree species of China } & Vegetation & & $10 \%$ & Wang et al. 2011 \\
\hline & Vegetation Removal & & $14 \%$ & \\
\hline Brosimum alicastrum & & $75 \%$ & $44 \%$ & Laborde and \\
\hline Enterolobium cyclocarpum & & $60 \%$ & $13 \%$ & $\begin{array}{l}\text { Corrales-Ferrayola } \\
2012\end{array}$ \\
\hline
\end{tabular}


Table 2a. Direct seeding field performance of tropical forest species - Continuation.

\begin{tabular}{|c|c|c|c|c|}
\hline 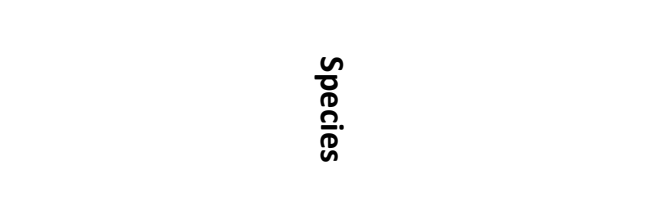 & $\frac{n}{\stackrel{n}{D}}$ & 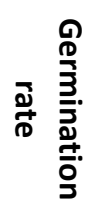 & 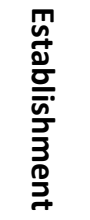 & 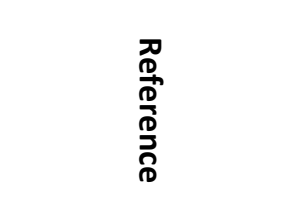 \\
\hline $\begin{array}{l}\text { Four species in Hawaiian Dry Forest } \\
\text { Ecosystem }\end{array}$ & Afforestation - Mowed & & $0 \%$ & $\begin{array}{l}\text { Ammondt et al. } \\
2013\end{array}$ \\
\hline $\begin{array}{l}12 \text { tree species in the Brazilian deciduous and } \\
\text { semideciduous forests }\end{array}$ & $\begin{array}{l}\text { Afforestation - grass canopy } \\
\text { Afforestation -no grass canopy }\end{array}$ & $\begin{array}{l}29 \% \\
20 \%\end{array}$ & & $\begin{array}{l}\text { de Souza Gomes } \\
\text { Guarino and Scariot } \\
2014\end{array}$ \\
\hline Afzelia xylocarpa & Afforestation & & $44 \%$ & Hossain et al. 2014 \\
\hline Eugenia cumini & & & $10 \%$ & \\
\hline Ficus racemosa & & & $5 \%$ & \\
\hline Gmelina arborea & & & $5 \%$ & \\
\hline Schleichera oleosa & & & $40 \%$ & \\
\hline Six Brazilian savanna species & Afforestation & $52 \%$ & $34 \%$ & Silva et al. 2015 \\
\hline Oreomunnea mexicana subsp. mexicana & Secondary forest & $37 \%$ & $7 \%$ & $\begin{array}{l}\text { Atondo-Bueno et } \\
\text { al. } 2016\end{array}$ \\
\hline & Average & $38 \%$ & $17 \%$ & \\
\hline
\end{tabular}

Common names were provided in some instances because the appropriate scientific names were not provided in the cited reference.

Table $2 b$. Direct seeding field performance of temperate hardwood species.

\begin{tabular}{|c|c|c|c|c|}
\hline $\begin{array}{l}\text { ñ } \\
\text { D } \\
\text { n. } \\
\text { D. }\end{array}$ & 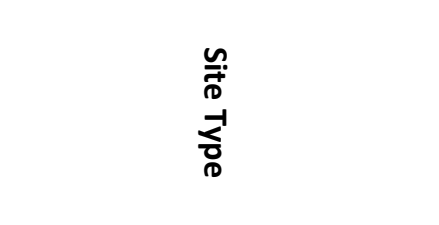 & 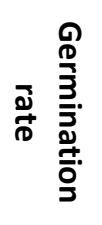 & 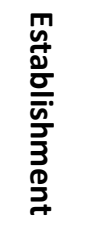 & $\begin{array}{l}D_{0} \\
\mathbb{D} \\
\frac{\mathbb{D}}{n} \\
\frac{\mathbb{D}}{2} \\
\stackrel{D}{D}\end{array}$ \\
\hline Quercus shumardii and Quercus phellos & Reforestation & & $35 \%$ & Wittwer 1991 \\
\hline Acacia sophorae & Afforestation & & $6 \%$ & Barron and Dalton 1996 \\
\hline Eucalyptus dioersifolia & & & $0 \%$ & \\
\hline Quercus pagoda & Reforestation & & $78 \%$ & Stanturf and Kennedy 1996 \\
\hline Quercus rubra & Under planted in plantation & & $50 \%$ & Trencia 1996 \\
\hline Quercus rubra & Reforestation & & $53 \%$ & Zaczek et al. 1997 \\
\hline Bottomland Forest Species & Reforestation & $35 \%$ & & Stanturf et al. 1998 \\
\hline Quercus nuffallii & Afforestation & & $15 \%$ & $\begin{array}{l}\text { Schweitzer and Stanturf } \\
1999\end{array}$ \\
\hline Quercus rubra & Reforestation - Multiple & & $29 \%$ & Parker et al. 2001 \\
\hline Fagus sylvatica & Reforestation - Multiple & & $23 \%$ & Ammer et al. 2002 \\
\hline Bottomland Forest Oaks & Reforestation & & $22 \%$ & Twedt and Wilson 2002 \\
\hline \multirow[t]{3}{*}{ Quercus liaotungensis } & Reforestation site - Large gap & $60 \%$ & $48 \%$ & Li and Ma 2003 \\
\hline & Reforestation - Small gap & $50 \%$ & $40 \%$ & \\
\hline & Reforestation - Understory & $43 \%$ & $32 \%$ & \\
\hline $\begin{array}{l}\text { Carya cordiformis, Betula } \\
\text { alleghaniensis, Fagus grandifolia, and } \\
\text { Juglans nigra }\end{array}$ & Uncolanized Woodlots & & $1 \%$ & Hewitt and Kellman 2004 \\
\hline Northofagus solandri var. cliffortioides & Reforestation & & $1 \%$ & Ledgard and Davis 2004 \\
\hline Leptospermum scoparium & & & $1 \%$ & \\
\hline
\end{tabular}


Table $2 b$. Direct seeding field performance of temperate hardwood species - Continuation.

\begin{tabular}{|c|c|c|c|c|}
\hline 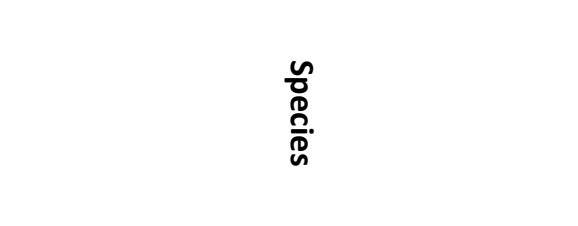 & $\frac{n}{\stackrel{n}{0}}$ & 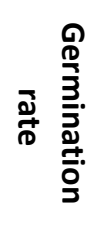 & 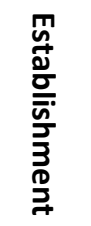 & $\begin{array}{l}\text { D } \\
\frac{D}{D} \\
\frac{D}{D} \\
\frac{D}{D} \\
D\end{array}$ \\
\hline $\begin{array}{l}\text { Operational planting of multiple } \\
\text { hardwood species in the United } \\
\text { Kingdom }\end{array}$ & Afforestation - Multiple & & $10 \%$ & Willoughby et al. 2004 \\
\hline Quercus petraea - Fenced for herbivore & Control $(\mathrm{Y})$ & & $56 \%$ & \\
\hline \multirow[t]{3}{*}{$\operatorname{control}(\mathrm{Y} / \mathrm{N})$} & Cover $\operatorname{Crop}(\mathrm{Y})$ & & $58 \%$ & \\
\hline & Weed Free (Y) & & $60 \%$ & \\
\hline & Weed Free $(\mathrm{N})$ & & $51 \%$ & \\
\hline \multirow[t]{2}{*}{ Quercus robur } & Reforestation (4 years) & & $50 \%$ & Madsen and Löf 2005 \\
\hline & Reforestation (4 years) & & $23 \%$ & \\
\hline Fraxinus excelsior & Reforestation & $30 \%$ & $21 \%$ & Jinks et al. 2006 \\
\hline Acer pseudoplatanus & Reforestation & $30 \%$ & $27 \%$ & \\
\hline Eucalyptus marginata & Afforestation & & $10 \%$ & Koch and Samsa 2007 \\
\hline \multirow[t]{3}{*}{ Quercus castaneifolia } & Site Fertility - low & $90 \%$ & $36 \%$ & Tabari and Asri 2008 \\
\hline & Site Fertility - medium & $90 \%$ & $43 \%$ & \\
\hline & Site Fertility - high & $90 \%$ & $65 \%$ & \\
\hline Quercus macrocarpa & Reforestation & $56 \%$ & $56 \%$ & Lalibert'e et al. 2008 \\
\hline Quercus robur & & $92 \%$ & $92 \%$ & \\
\hline \multicolumn{5}{|l|}{ Zealand } \\
\hline Quercus robur & With Tree Shelters & & $56 \%$ & Valkonen 2008 \\
\hline Quercus ilex & Reforestation site_Multiple & $45 \%$ & $29 \%$ & Mendozza et al. 2009 \\
\hline Quercus pyrenaica & & $41 \%$ & $26 \%$ & \\
\hline Acer granatense & & $9 \%$ & $4 \%$ & \\
\hline Sorbus ariea & & $19 \%$ & $9 \%$ & \\
\hline Quercus nuttallii & Afforestation & & $12 \%$ & Stanturf et al. 2009 \\
\hline \multirow[t]{2}{*}{ Mixed species in lowland British forest } & Reforestation & & $20 \%$ & Willoughby and Jinks 2009 \\
\hline & $\begin{array}{c}\text { Reforestation site with } \\
\text { herbicides }\end{array}$ & & $40 \%$ & \\
\hline Quercus palustris & Reforestation site - Multiple & & $10 \%$ & Motsinger et al. 2010 \\
\hline Quercus ilex & Afforestation & & $12 \%$ & González-Rodríguez et al. \\
\hline Quercus suber & & & $22 \%$ & 2011 \\
\hline Populus fremontii & Reforestation & & $7 \%$ & Grabau et al. 2011 \\
\hline Salix gooddingii & & & $1 \%$ & \\
\hline Betula pendula and B. pubescence & Reforestation & & $31 \%$ & Rouvinen and Koulki 2011 \\
\hline Quercus robur & Afforestation & & $53 \%$ & St Denis et al. 2013 \\
\hline Acer saccharum & & & $3 \%$ & \\
\hline Nine Austrailian pioneer tree species & Restoration - Multiple & & $1 \%$ & Florentine et al. 2013 \\
\hline Prunus pensylvanica & Afforestation & $4 \%$ & $3 \%$ & Smreciu and Gould 2015 \\
\hline \multirow[t]{2}{*}{ Prunus virginiana } & & $12 \%$ & $8 \%$ & \\
\hline & Average & $47 \%$ & $28 \%$ & \\
\hline
\end{tabular}


Table 2c. Direct seeding field performance of temperate conifer species.

\begin{tabular}{|c|c|c|c|c|}
\hline $\begin{array}{l}\text { n } \\
\text { D } \\
\stackrel{n}{D} .\end{array}$ & 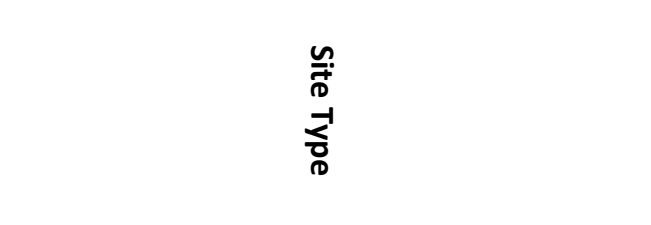 & 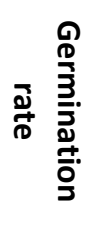 & 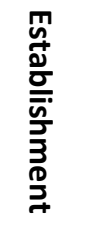 & $\begin{array}{l}\text { D } \\
\frac{\mathbb{D}}{\mathbb{D}} \\
\frac{D}{D} \\
\frac{D}{D} \\
\stackrel{D}{D}\end{array}$ \\
\hline Pinus taeda & Reforestation & $12 \%$ & $3 \%$ & Huebschmann and Wittwer 1992 \\
\hline Picea mariana & Reforestation & & $35 \%$ & Groot and Adams 1994 \\
\hline \multirow[t]{2}{*}{ Pinus sylvestris } & Reforestation & $42 \%$ & $34 \%$ & Winsa and Bergsten 1994 \\
\hline & Reforestation & $63 \%$ & $52 \%$ & \\
\hline \multirow[t]{2}{*}{ Picea mariana } & Reforestation - Mineral/humus interface & & $8 \%$ & Fleming and Mossa 1994 \\
\hline & Reforestation - Surface & & $1 \%$ & \\
\hline \multirow[t]{3}{*}{ Picea mariana } & Reforestation - Litter seedbed & & $2 \%$ & Fleming and Mossa 1995 \\
\hline & Reforestation - Thin organic matter seedbed & & $23 \%$ & \\
\hline & Reforestation - Shallow mineral seedbed & & $20 \%$ & \\
\hline \multirow[t]{5}{*}{ Picea glauca } & Reforestation - Mound seedbed & & $6 \%$ & DeLong et al. 1997 \\
\hline & Reforestation - Rotten log seedbed & & $7 \%$ & \\
\hline & Reforestation - Exposed seedbed & & $11 \%$ & \\
\hline & Reforestation - Normal seedbed & & $5 \%$ & \\
\hline & Reforestation - Screef seedbed & & $7 \%$ & \\
\hline Pseudotusuga & Reforestation - VEG - None & & $34 \%$ & Caccia and Ballaré 1998 \\
\hline \multirow[t]{2}{*}{ menziesii } & Reforestation - VEG - Medium & & $30 \%$ & \\
\hline & Reforestation - VEG - High & & $10 \%$ & \\
\hline Abies balsamea & Conifer forest & $30 \%$ & $12 \%$ & Cornett et al. 1998 \\
\hline Pinus strobus & & $36 \%$ & $8 \%$ & \\
\hline \multirow[t]{2}{*}{ Pinus sylvestris } & Reforestation - No site preparation & & $10 \%$ & Wennström et al. 1999 \\
\hline & Reforestation - Microsite preparation & & $15 \%$ & \\
\hline Picea glauca & Reforestation & $28 \%$ & $15 \%$ & Stewart et al. 2000 \\
\hline Pinus sylvestris & Reforestation & $88 \%$ & $45 \%$ & de Chantal et al. 2004 \\
\hline Picea abies & & $72 \%$ & $17 \%$ & \\
\hline \multirow[t]{3}{*}{ Pinus sylvestris } & Reforestation & & & Nilson and Hjältén 2003 \\
\hline & Open & $73 \%$ & $9 \%$ & \\
\hline & Closed canopy & $60 \%$ & $15 \%$ & \\
\hline \multirow[t]{5}{*}{ Pinus sylvestris } & Afforestation - Fenced for herbivore control & & & Willoughby et al. 2004 \\
\hline & Control $(\mathrm{Y})$ & & $4 \%$ & \\
\hline & Cover Crop (Y) & & $5 \%$ & \\
\hline & Weed Free $(Y)$ & & $9 \%$ & \\
\hline & Weed Free $(\mathrm{N})$ & & $0 \%$ & \\
\hline \multirow[t]{2}{*}{ Pinus sylvestris } & Reforestation - Stand Seed & & $38 \%$ & Wennström et al. 2007 \\
\hline & Reforestation - Orchard Seed & & $43 \%$ & \\
\hline Pinus sylvestris & Reforestation - Multiple & $26 \%$ & $6 \%$ & Erefur et al. 2008 \\
\hline Picea abies & & $27 \%$ & $7 \%$ & \\
\hline Picea mariana & Reforestation & & $17 \%$ & Gauthier and Ruel 2008 \\
\hline Pinus sylvestris & Reforestation & $55 \%$ & $1 \%$ & Mendozza et al. 2009 \\
\hline Pinus kesiya & Reforestation & & $38 \%$ & Sovu et al. 2010 \\
\hline Pinus resinosa & Afforestation & & $6 \%$ & St Denis et al. 2013 \\
\hline \multirow[t]{2}{*}{ Thuja plicata } & Reforestation & $31 \%$ & $0 \%$ & Sheridan et al. 2016 \\
\hline & Average & $46 \%$ & $16 \%$ & \\
\hline
\end{tabular}




\subsection{Factors Affecting Conversion Rates}

\section{Seed Parameters}

Knowing which tree species have suitable characteristics for direct seeding is critical to the success of forest restoration projects that rely on direct seeding (Tunjai and Elliott 2011). In general, species used for direct seeding must be stress tolerant, have fast germination, establishment and initial growth, and a certain degree of shade tolerance (Schmidt 2008), though site conditions will dictate the selection of tree species and seed source. Local seed sources of early-successional and pioneer species, with their ability to grow rapidly, and late-successional and climax tree species with large seeds and food reserves (Piggott et al. 1987; Pandey and Prakash 2014) can be successfully established. Population size and the initial genetic diversity of trees selected for seed collection can have strong effects on seed quality, germination and survival, which affects genetic diversity in future generations (Ivetić et al. 2016b). To maintain a high level of genetic diversity in the new forests, the use of reproductive material originating from well-designed seed orchards, the use of seed mixtures from different seed sources and provenances, and the use of seed collected from trees of different ages are recommended (Ivetić and Devetaković 2016b, 2017).

Poor seed germination rates (Holl et al. 2000; Engel and Parrotta 2001) or small seed size (i.e. smaller seeds performed poorly) (Camargo et al. 2002; Hooper et al. 2002; Doust et al. 2006 and 2008; González-Rodríguez et al. 2011) have resulted in low establishment rates. Large seeded species (Hooper et al. 2002; Birkedal 2010; Tunjai and Elliott 2011; St-Denis et al. 2013) and greater seed weights tend to result in better germination (Zimmerman et al. 2000; de Souza Gomes Guarino and Scariot 2014) and establishment rates (Camargo et al. 2002; Hooper et al. 2002; Doust et al. 2006; Wang et al. 2011; Hossain et al. 2014). Stanturf and associates (1998) found that only heavyseeded species of Quercus spp. and Carya spp. have the capability to be successfully direct-seeded. In examining all trials that direct seeded temperate hardwoods (Table $2 \mathrm{~b})$ the average establishment rate for oak species was $45 \%$ compared to only $10 \%$ for all other hardwood species. One benefit of large seeds in direct seeding programs is that their larger store of carbohydrates improves seedling establishment (Khurana and Singh 2001).

However, some studies report a weak association between seed weight and germination (de Souza Gomes Guarino and Scarion 2014). This is because other factors such as seed form and moisture content also affect their establishment (Tunjai and Elliott 2011). Small seeds and seeds with low water content have less susceptibility to desiccation in dry regions, and have a comparatively better potential to enter disturbed soil when broadcast seeded (Pandey and Prakash 2014). Seed size along with seeding practice can influence establishment success because seed burial had a negative effect on emergence of flat seed species compared to round seed species (Silva et al. 2017). A number of recent reviews found that, in general, seed size improves subsequent seedling establishment, though not in all situations (Ceccon et al. 2016; Figure 3), making it difficult to make generalized statements related to seed quality and direct seeding success. 


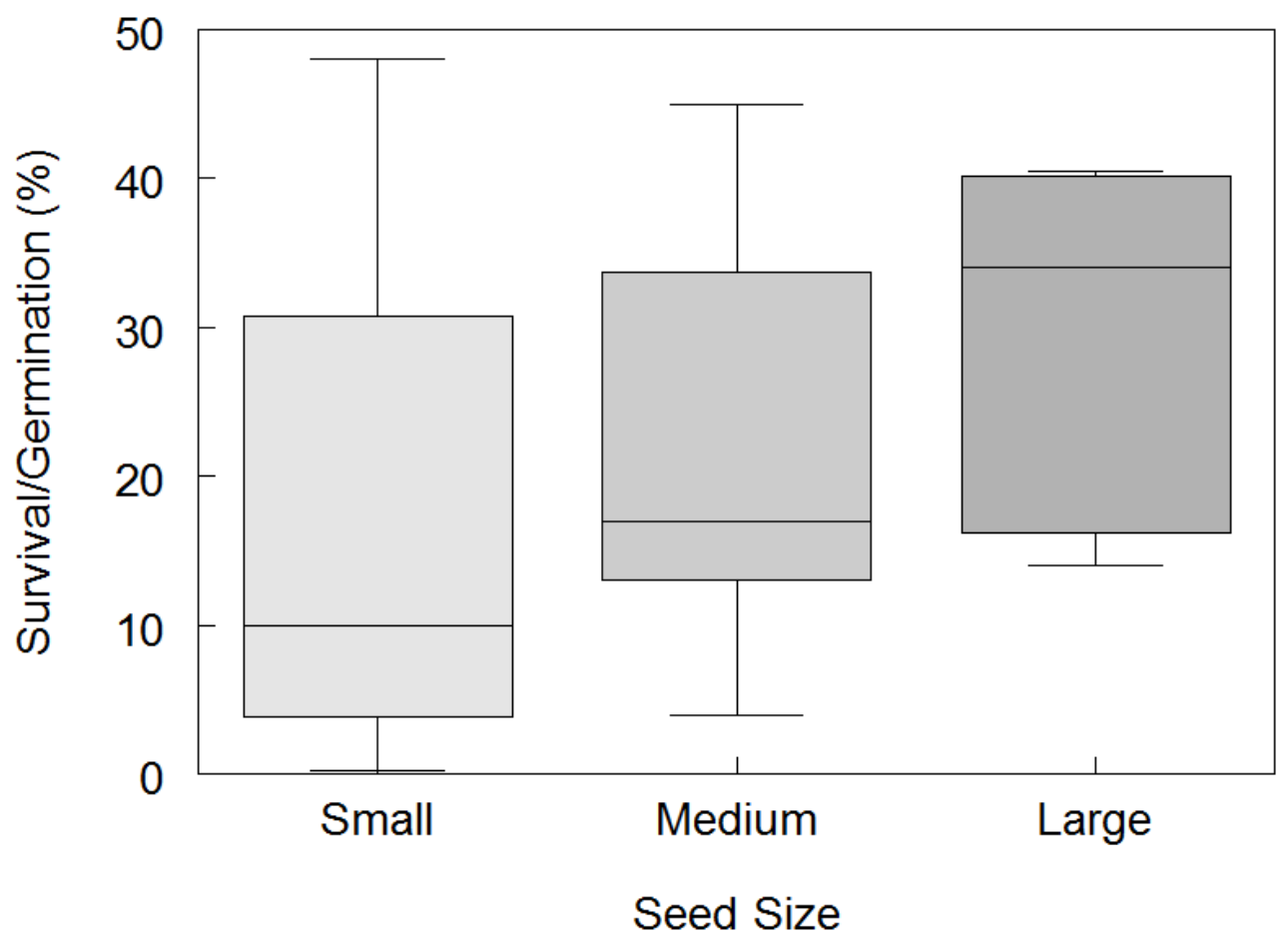

Figure 3. Survival/germination (box plots with median, box out to the $1^{\text {st }}$ and $3^{\text {rd }}$ quarterlies with whiskers to 1.5 times the interquartile range) in relation to seed size (mass) for direct seeding trials where the seed size categories were small (0$99 \mathrm{mg}-\mathrm{n}=29)$ medium $(100-2000 \mathrm{mg}-\mathrm{n}=14)$ and large $(>2000 \mathrm{mg}-\mathrm{n}=6)$ (adapted from Pamela and Laurence 2015).

Germination speed and seed dormancy also affect seedling establishment rate after direct seeding. There are reports of seed germination occurring in 2 to 4 years after direct seeding, due to seed biology (Löf et al. 2004), or environmental conditions (Petursson and Sigurgeirsson 2004). Species with a weak seed dormancy sown in spring typically emerge after a few months, and species with deep seed dormancy can emerge up to a year later after a long exposure to site conditions (Frochot et al. 2009). Deep dormant seed must be pre-treated before direct seeding (Schmidt 2008), because delayed germination can lead to extended need for vegetation and predation control on restoration sites. Untreated dormant seed allow better flexibility in terms of seeding time, while pretreated seed must be sown when dormancy is broken (Frochot et al. 2009). Thus, knowledge of seed biology is necessary in planning a direct seeding program.

The use of high quality seed is imperative because it increases the early success by improving the establishment rate, and also forest stand performance due to increased genetic gain. Genetic variability of seed can have a significant effect on field performance. For example, seeds of Pinus sylvestris from seed orchards increased direct seeded seedling establishment by $41 \%$ (Wennström et al. 1999), as well as resulting in 
taller seedlings four years after seeding compared to seed from natural stands (Wennström et al. 2007). Survival of Pinus sylvestris seedlings from direct seeding was improved with better seed quality (Winsa and Bergsten 1994). A cost-benefit analysis showed that, the net cost of Pinus sylvestris orchard seed was less than that of natural stand seed, with $7 \%$ yield improvement and $15 \%$ better seed quality (Ahtikoski and Pulkkinen 2003). Providing enough high-quality seed for direct-seeding programs is an issue because seeding rates are much higher than nursery seeding rates (See Direct Seedling - Recommended Seeding Rates section). One possible solution would be the availability of seeds from seed orchards via low-budget breeding programs (Lindgren 2016).

Seeding should occur when site environmental conditions are least stressful. "Ultimately success will depend on timing emergence so that emergence and survival of seedlings is maximized" (Jinks et al. 2006). The best time for seeding is when they have the best chance of germination; which means plentiful moisture, optimum temperature, minimal weed competition, and a potentially favorable growing season before exposure to stressful environmental conditions (Schmidt 2008). Soil nutrition, while important, is a secondary factor in seed germination and initial seedling establishment. The following examples show that the season to ensure the best seed germination and establishment changes with species and forest ecosystem.

Spring

- Spring seeding of oak acorn generally gave better results than autumn seeding (Madsen and Löf 2005).

- Major southern US pine species were best sown in the spring after seed stratification (Barnett 2014).

- Spring seeding of Pinus concorta, Pinus mugo and Alnus viridis was more successful than autumn seeding except on sites covered with snow throughout the winter (Ledgard 1976).

- Twenty woody species in France favored spring seeding with buried seed (Frochot et al. 2009).

- Pinus banksiana stand regeneration was significantly better after spring than fall seeding (Chrosciewicz 1990).

- Spring direct seeding of Pinus sylvestris and Picea abies resulted in greater seedling establishment (Figure 4) and resulted in larger seedlings after three years compared to summer-sown seeds (de Chantal et al. 2004).

Fall

- Fall planting of oak seeds in Iberian woodlands is recommended because of seasonal rains (Sánchez-González et al. 2016).

- Fall seeding is generally recommended for Pinus palustris because their seeds germinate naturally in the fall (Barnett 2014).

- Fall seeding Spartium junceum on an afforestation site resulted in successful germination and survival (Brofas and Karetsos 2002). 


\section{Winter}

- Seeding time was the most significant variable in the Western Australian wheatbelt; with seeds sown in the winter out-performing later seeding times (Piggot et al. 1987).

- Jinks et al. (2006) recommended seeding in late winter for Fraxinus excelsior and Acer pseudoplatanus, though winter conditions (i.e. waterlogged soils and frost) can limit seedling emergence.

\section{Multiple Seasons}

- Temperate hardwoods, in the Lower Mississippi Alluvial Valley, had successful establishment across multiple seasons (i.e. November through June) (Stanturf et al 1998).

Ultimately, timing of direct seeding is dictated by the time of year providing the best chance of maintaining consistently optimum environmental conditions that once seeds germinate, young seedlings avoid planting stress and become established. For example, in the tropical dry forests planting seeds when the soil has sufficient moisture in the rainy season can increase seedling establishment (Vieira and Scariot 2006), while in the northern latitude forests spring season planting is only optimal during years when there is soil moisture (de Chantal et al. 2004). Just like planted seedlings, young seedlings from direct seeding need to grow a root system into the soil to achieve a proper water balance as they become coupled with the hydrologic cycle of the planting site (Burdett 1990; Margolis and Brand 1990; Grossnickle 2005). For example, a two month delay of seedling emergence for direct sown oak resulted in the equivalent of one year's growth reduction; which was attributed to the exposure to dry summer conditions (Löf and Birkedal 2009).

\section{Seeding Practices}

Seed burial, versus broadcast seeding, was found to improve establishment rates (Negreros-Castillo et al. 2003; Woods and Elliot 2004; Doust et al. 2006; GarcíaOrth and Martínez-Ramos 2008; Sovu et al. 2010). Broadcast seeding is applied in restoration programs because it has the advantage of covering a large area in an efficient manner as well as providing a means to seed remote areas and difficult terrain (Schmidt 2008). The disadvantage of broadcasting is that seeds lie on the ground, exposing them to harsh environmental conditions and predation (discussed in following sections), which can result in very low establishment rates (Ledgard and Davis 2004; Ammondt et al. 2013; Florentine et al. 2013). However, broadcast seeding when combined with proper site and seedbed preparation and vegetation control can be a successful practice (Brooks et al. 2009).

Site preparation techniques that improved the seedbed (i.e. remove competition and create seeding spots near the mineral soil - humus interface) can increase seed germination and seedling establishment (Loewenstein and Pitkin 1966; Fleming and Mossa 1994; Wennström et al. 1999; Oleskog and Sahlén 2000; Hille and den Ouden 2004; Ledgard et al. 2008; Birkedal et al. 2010). Corenett et al. (1998) found reduction in thickness of the forest floor organic layer beneficial for direct seeding of Abies balsamea but not Pinus strobus. Direct seeding of Pinus sylvestris and Picea abies resulted in greater seedling establishment when soil scarification exposed seeds to the Ae-B Horizon (Figure 4). Seeding immediately after the site preparation treatment is best because the receptivity of the seedbed declines with the passing of each growing 
season (Fleming and Mossa 1995). Interestingly, the combination of soil scarification and a dense shelterwood system (300 stems ha- ${ }^{1}$ ) resulted in higher survival of direct seeded Picea stichensis (Farrelly et al. 2003), indicating that managing the entire environment of the restoration site can be critical for ensuring successful establishment.

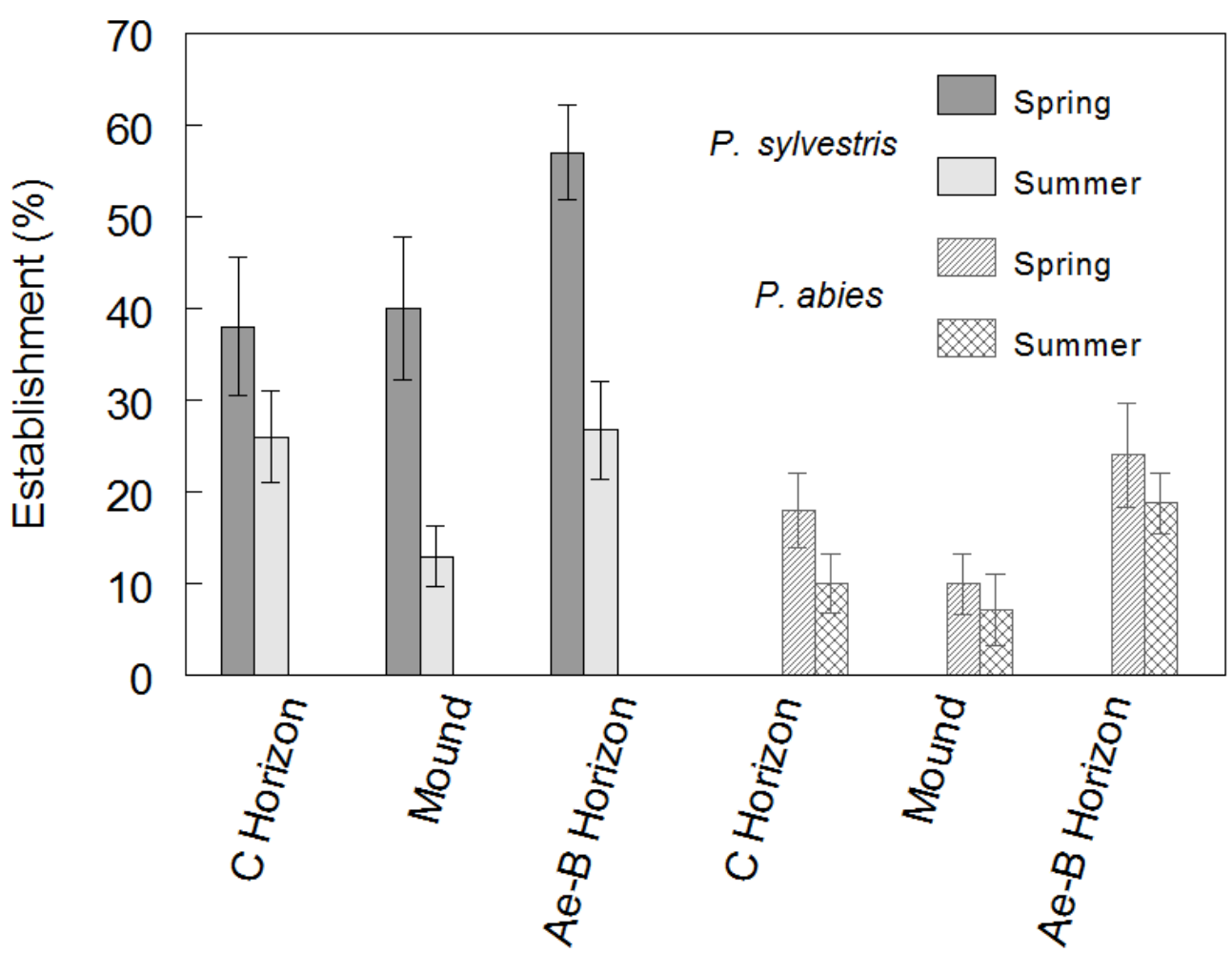

Figure 4. Third year establishment (mean +/- SE) of direct seeded Pinus sylvestris and Picea abies in relation to planting season and site preparation treatment (i.e. Exposed C Horizon, Mound, or Exposed Ae-B Horizon) after being planted during a moist growing season on a clearcut reforestation site (adapted from de Chantal et al. 2004).

Spot seeding has long been considered a direct seeding option (Toumey 1916). Seeds are usually sown in spots prepared by raking, hoeing, or kicking areas free of vegetation and litter (Barnett 2014). However, ploughed furrows, or scalps to mineral soil, are also effective site preparation techniques to create seeding spots (Stiell 1959). Tractor-mounted seeders have been used and usually result in seeds sown in rows (Schmidt 2008; Barnett 2014). Spot seeding was far more successful than broadcast seeding in conversion of hardwood stands on poor sites for Pinus strobus (Wendel 1971), while mechanized seeding of Pinus sy/vestris produced better results than manual seeding (Kankaanhuhta et al. 2009).

Covering seeds to the proper planting depth enhances seeding results (Nilsson et al. 1996; Li and Ma 2003; Negreros-Castillo et al. 2003; Nilson and Hjältén 2003; Doust et al. 2006; Sovu et al. 2010). Typically the best seeding depth depends on seed size. A 
general rule is that seeding depth is between one and two times the seed width. This observation is supported by nursery experiments that indicated depth of seeding requirements for a range of native species depending on their seed size: large seeded trees and shrubs, particularly Acacia spp. and Eucalyptus calophylla, required soil covering of 5-10 mm, while smaller-seeded Eucalyptus spp. performed best with a soil covering of 2-5 mm, although good results were achieved for some species by surface seeding (Piggot et al. 1987). Seeding oak seeds from 2.5 to $15 \mathrm{~cm}$ deep is recommended depending on acorn size (Johnson and Krinard 1985), with deeper seeding beneficial if soil drying or rodent damage are likely (Stanturf et al. 1998; Oliet et al. 2015). However, soil-buried seeds do not always attain higher germination rates than surface seeding (Pandey and Prakash 2014). In dry tropical forests buried seeds did not have higher germination than broadcast seeds as long as a grass cover provided safety from seed predators and a suitable microclimate with soil moisture similar to the forest (de Souza Gomes Guarino and Scariot 2014). Though there are general rules for proper planting depth, there is enough inconsistency to show that species and site conditions ultimately dictate seeding practices.

Direct seeding success is primarily related to site conditions that make soil water available during the germination and establishment phases (Laman 1995; Knight et al 1997; Stanturf et al. 1998; Oleskog and Sahlén 2000; Engel and Parrotta 2001; Ammer et al. 2002; Chantal et al. 2003; Pausas et al 2004; Woods and Elliot 2004; Jinks et al. 2006; Dodd and Power 2007; Gauthier and Ruel 2008; Laliberté et al. 2008; Mendoza et al 2009; Bonilla-Moheno and Holl 2010; Wang et al. 2011; Florentine et al; 2013; Atondo-Bueno et al. 2016; Helenius 2016). For example, the probability of seedling emergence for Oreomunnea mexicacana was directly related to soil water availability with seedling emergence increasing with more available soil water (Figure $5 \mathrm{~A}$ ), though flood prone sites require practices that enhance soil drainage (Gardiner et al. 2004). In a study examining seedling establishment based on location of planting in the soil profile, establishment success was best as soil water availability increased to an optimum level, with the actual best location in the profile changing as soil water status changed (Fleming and Mossa 1989). In a study confirming these observations, the performance of direct seeded Pinus sylvestris and Picea abies (data from over thirteen thousand operative forest regeneration quality management inventory sites), soil water (along with site preparation and the seeding into mineral soil) was the primary factor(s) affecting direct seeding success (Kankaanhuhta et al. 2009).

The availability of soil water is affected by soil type where direct seeding is applied and the best establishment rate typically occurs on bare mineral soil (Riley 1973; Wittwer 1991; DeLong et al. 1997; Knight et al. 1997; Caccia and Ballaré 1998; Carmargo et al. 2002; Hanssen 2002; de Chantal et al. 2005; Madsen and Löf 2005; Stevenson and Smale 2005) where removing the organic soil layer improves continuous water availability which is critical for germinating seeds (Hille and den Ouden 2004). The recommended seedbed for best seedling establishment from direct seeding in northern latitude forests is reported to be mineral soils that are still "fresh"; meaning the disturbed soil has not had time to settle, thereby providing spaces where seeds can settle before the soil becomes compacted with plentiful, but not excessive soil water and moderate temperature conditions $\left(\sim 10-25^{\circ} \mathrm{C}\right)$; with nutrition not a noted concern (Fleming et al. 2001). However, there are exceptions to planting in mineral soil. For example, poorly decomposed Sphagnum peat was the best seedbed for black spruce 
(Groot 1994); a species typically found on wet low lying northern latitude forest bog sites (Harlow and Harrar 1969). Though mineral soils are a preferential seedbed, in northern latitude forests, seeds planted in open sites can incur injury and/or mortality due to frost heaving (Erefur et al. 2008), indicating that site selection for direct seeding needs to consider conditions across all seasons.
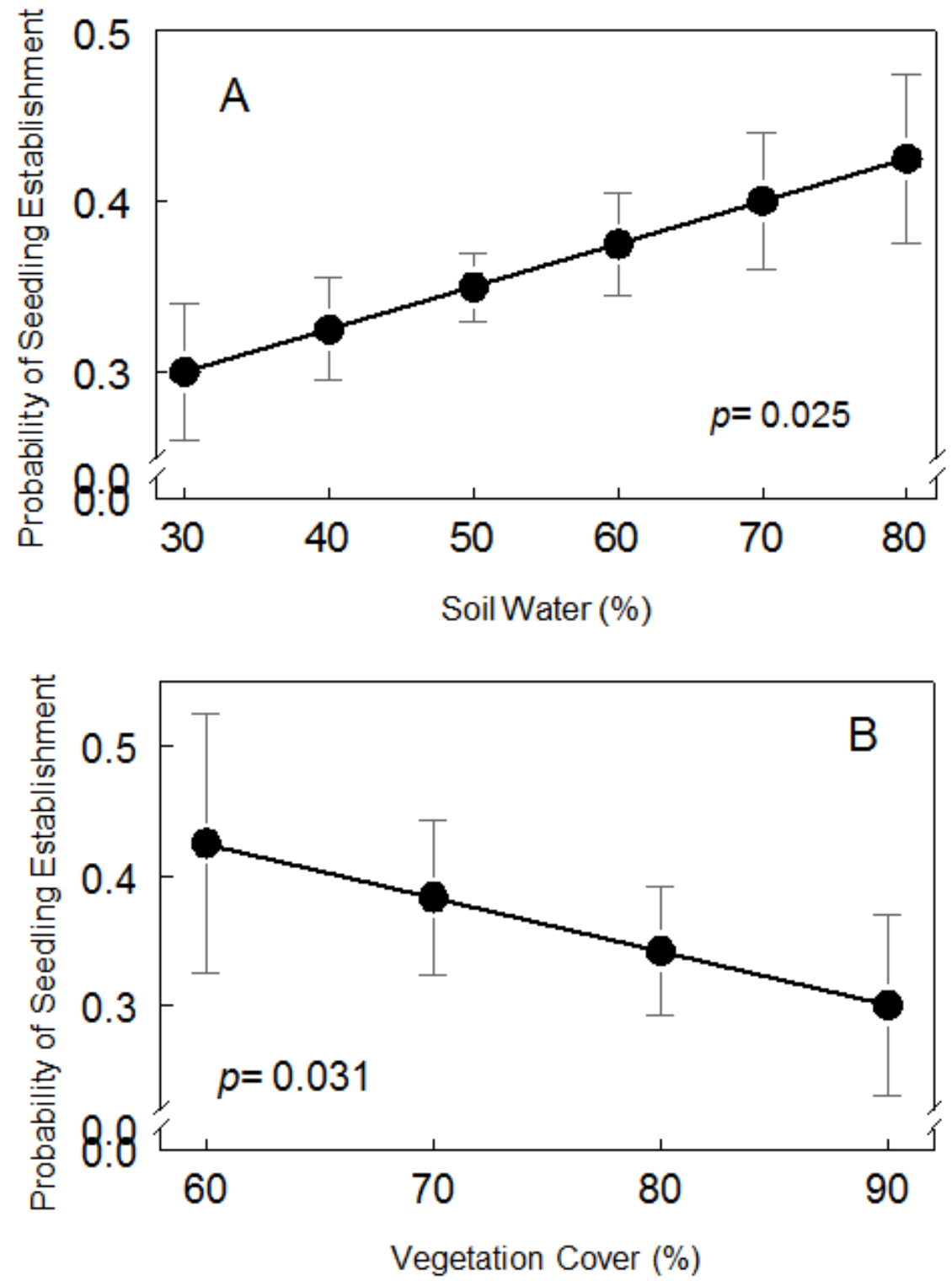

Figure 5. Probability of seedling establishment from direct seeding of Oreomennea mexicana under field conditions in relation to site soil water content (A) and vegetation cover (B) (adapted from Antondo-Bueno et al. 2016). Note: Bars through data points represent the $95 \%$ confidence interval. 


\section{Competitive Vegetation}

Competition for site resources is one of the major factors limiting the successful establishment and growth of seedlings (Gjerstad et al. 1984; Sutton 1985; Radosevich and Osteryoung 1987; Grossnickle 2000). For example, the probability of seedling emergence for Oreomunnea mexicacana decreased with greater vegetation cover (Figure 5B). Competition from site vegetation has resulted in low conversion rates in direct seeded programs (Winsa and Bergsten 1994; Sun et al. 1995; Knight et al. 1997; Cornett et al. 1998; Holl et al. 2000; Engel and Parrotta 2001; Camargo et al. 2002; Hooper et al. 2002; Löf and Welander 2004; Stevenson and Smale 2005; Vieira and Scariot 2006; Doust et al 2008; Valkonen 2008; Motsinger et al. 2010; Grabau et al. 2011).

Control of grasses, forbs, and shrubs is required to ensure the proper environment (e.g. favorable light conditions, adequate soil moisture, available nutrients) for desirable seedling physiological response to result in better survival and growth (reviewed by Grossnickle 2000). A standard site preparation for direct seeding is to remove competitive vegetation by cutting, hoeing, use of herbicides, burning or mechanical removal (Schmidt 2008; Barnett 2014). In direct seeded studies where herbicides were applied to reduce plant competition establishment rates increased over control plots (Barron and Dalton 1996; Jinks et al. 2006; Ledgard et al. 2008; Balandier et al. 2009; Brooks et al. 2009; Willoughby and Jinks 2009). However, a strong response to herbicide application is not always reported (Wittwer 1991; Wang et al. 2011). Timing of herbicide application is critical because it can be damaging to emerging seedlings (Willoughby et al. 2003). The application of herbicides is an option, though caution needs to be applied to maximize benefits of this vegetation management treatment.

Not all existing vegetation at planting sites should be considered weeds, competing for energy, water, and nutrients of the direct seeded species (Ivetić and Devetaković 2016a). Under certain conditions the presence of vegetation cover promoted seedling emergence and survival in direct seeding programs (Ledgard 1976; Huebschmann and Wittwer 1992; Morris et al. 2000; Zimmerman et al. 2000; Hooper et al. 2002; Vieira and Scariot 2006; Bonilla-Moheno and Holl 2010; Davis et al. 2013; Avendaño-Yáñez et al. 2014, 2016; de Souza Gomes Guarino and Scariot 2014; Silva et al. 2015; Atondo-Bueno et al. 2016). In some instances seeds can attain higher germination under a grass canopy than on bare ground (de Souza Gomes Guarino and Scariot 2014), because grass cover protects from predators and improves microsite conditions. Exposed restoration sites can have a wide range of temperature and evaporative demand conditions, which can sometimes create planting stress (Grossnickle 2000). Compared to bare ground, seeds under grass canopy attain higher germination, but not the subsequent establishment of young seedlings (Pandey and Prakash 2014). Thus, one needs to consider whether vegetation cover is required to ameliorate extreme stressful site conditions that can affect seed germination or young seedlings growth.

Seed Predation

Seeds sown in the field are exposed to diseases, insects and rodents, which can result in low establishment rates. Predator activity is one of the major reasons for losses incurred in direct seeding programs (Caccia and Ballaré 1998; Cornett et al. 1998; Holl et al. 2000; Howlett and Davidson 2003; Hewitt and Kellman 2004; Pausas et al. 2004; Woods and Elliot 2004; Madsen and Löf 2005; Jinks et al. 2006; Vieira and Scariot 2006; Wennström et al. 2007; Erefur et al. 2008; Leverkus et al. 2013; de Souza Gomes Guarino 
and Scariot 2014; Helenius 2016). For example, seed predation can occur rapidly or gradually, but still over $80 \%$ of seed predation of Pinus halepensis occurred during the first six months after seeding (Figure 6). Jinks et al. (2012) suggested that species producing large nuts are more vulnerable to predation-loss and might require additional measures, such as treatment with repellents, to reduce the predation risk.

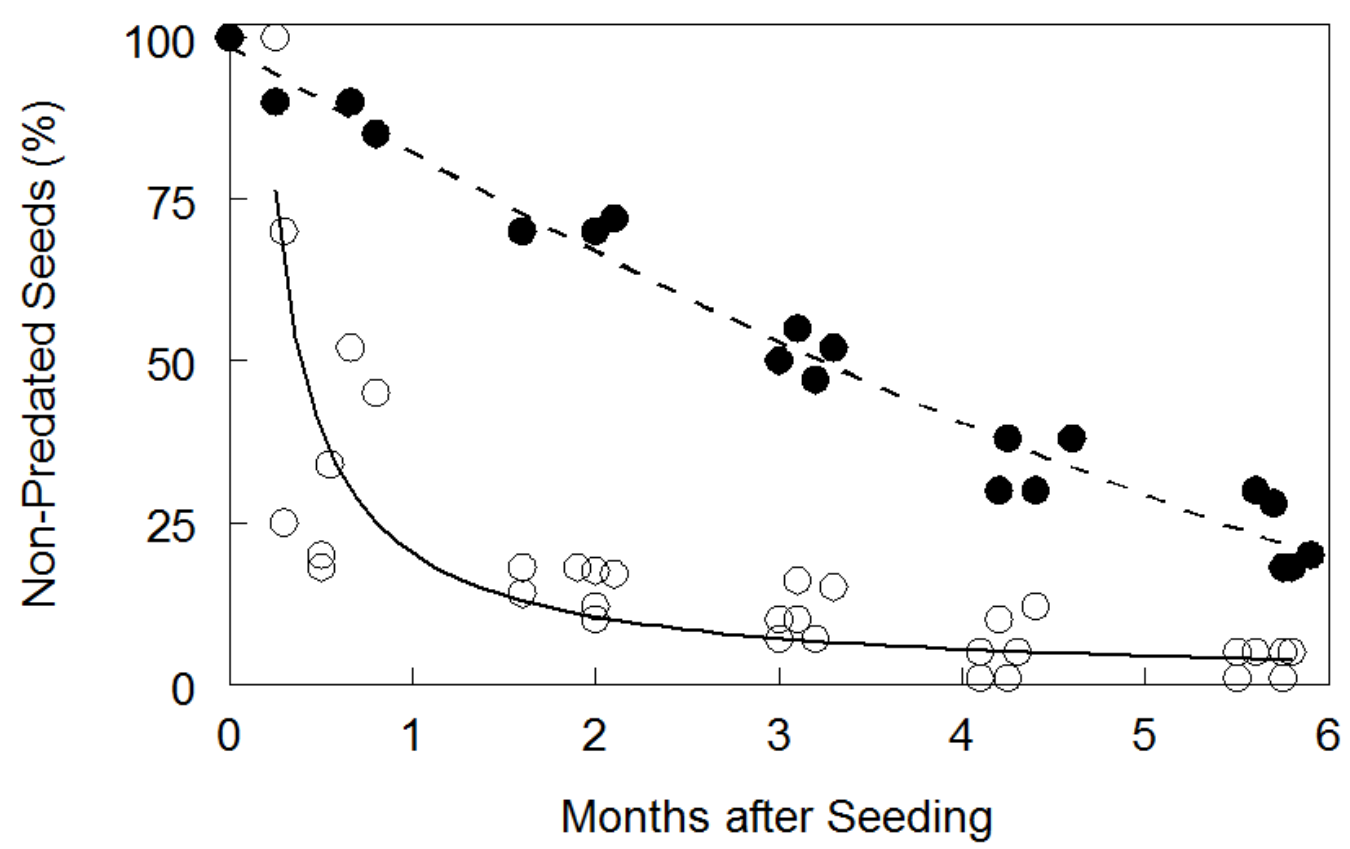

Figure 6. Percent seed predation (two response patterns over time) in an aerial seeding program with Pinus halepensis in a burned over area in Spain (adapted Pausas et al. 2004).

The uses of pesticides and rodenticides, as well as repellents or physical barriers are considered an option to prevent seed losses in direct seedling programs. For example, studies reported effective use of repellents to reduce rodent damage, with little effect on the seed germination (Barnett 1998, Nolte and Barnett 2000; Villalobos et al. 2017). However, repellents (Curtis et al. 1998) or cages (Caccia and Ballaré 1998) for Pseudotsuga menziesii seeds had limited success in preventing seed predation. In a study examining snap-trapping or raptor perches, neither resulted in increased direct seeded oak establishment (Birkedal et al 2009). This shows that these treatments cannot be considered a panacea to alleviate the seed predation problem.

Another suggested solution to reduce seed predation is the use of alternative foods to feed the rodent population and keep them from feeding on the tree seed crop. In one instance, the use of alternative food improved survival of conifer seed, via reduction of predation by rodents and birds (Sullivan and Sullivan 1984). Sullivan and 
Sullivan (1984) felt that rodents preferred larger seeds of an alternative food source because they had greater food value. However, large field trials with both conifer and hardwood species found no benefits of a wheat cover crop to protect seedlings from browsing mammals (Willoughby et al. 2004).

Covering newly sown seeds is another option to reduce seed predation. A simple covering of soil on tropical (de Souza Gomes Guarino and Scariot 2014), temperate hardwood (Nilsson et al. 1996) and conifer (Nilson and Hjältén 2003) seeds with soil reduced losses from predation. Thus, covering seed may be an operational practice to reduce seed predation and increase the success rate of direct seeding programs.

\section{Direct Seeding versus Seedling Comparison}

The two main options available for the establishment of a forest stand on a restoration site are either direct seeding or planting of seedlings. Bareroot and container-grown seedlings are the two basic stocktypes used in forest restoration programs (reviewed by Grossnickle and El-Kassaby 2016). If one is to consider direct seeding, then one needs to understand how this practice performs in comparison to alternative means of establishing a forest stand (i.e. survival rate and growth).

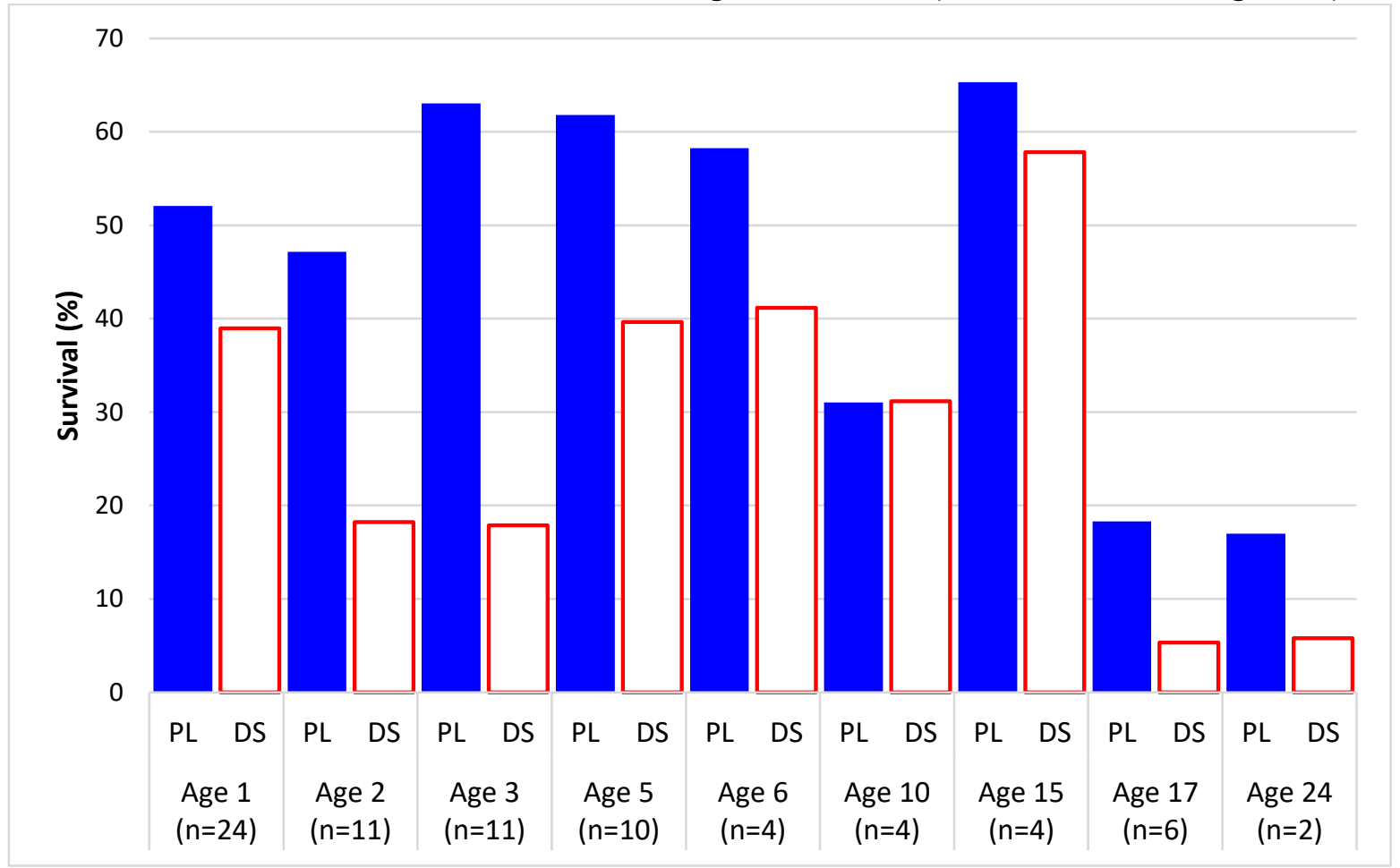

Figure 7. Survival comparison between planted seedlings (PL) and direct seeding (DS) for ages 1 to 24 after field planting

for a range of broadleaved and conifer species (Acacia saligna; Castanea dentata $\times$ C. mollissima; Eucalyptus gomphocephala; Picea abies; Pinus albicaulis; Pinus elliottii; Pinus flexilis; Pinus kesiya; Pinus sylvestris; Pinus taeda; Quecus ilex; Quercus nigra; Quecus nuttalli; Quercus pagoda; Quercus palustris; Quercus shumardii; Quercus suber). All studies report both PL and DS field survival (only control treatments reported) (Noble 1985; Huebschmann and Wittwer 1992; Haywood and Barnett 1994; Ozalp et al. 1998; Williams and Craft 1999; Pausas et al. 2004; Varmola et al. 2004; Fields-Johnson et al. 2010; Motsinger et al. 2010; Smith et al. 2011; So 2011; Gonzales-Rodrigues et al. 2011; DeMastus 2013). Filled bars represent survival percentage of planted seedlings and empty bars represents survival percentage of direct seeded seedlings. 
Trials comparing planted seedlings to direct seeding found that planted seedlings had a significantly higher rate establishment rate (i.e. up to $40-60 \%$ higher) (Wendel 1971; Campbell 1981; Noble 1985; James 1990; Huebschmann and Wittwer 1992; Ray and Brown 1995; DeLong et al. 1997; Schweitzer et al 1997; Williams and Craft 1998; Williams et al. 1999; Twedt and Wilson 2002; Löf et al. 2004; Dey et al. 2008; Motsinger et al. 2010; Cole et al. 2011; So 2011; Ammondt et al. 2013). These findings are corroborated in a recent review that found that on average planted seedlings had survival rates that were $44 \%$ higher (Pamela and Laurence 2015). In addition, higher survival rates continue well out into stand establishment, indicating that direct seeding will produce forest stands with a lower number of trees than planting seedlings (Figure 7), though in certain instances this practice has similar field survival as planted seedlings (Haywood and Barnett 1994 and Figure 7). In most cases direct seeding, compared to the planting of seedlings results in a lower rate of stand establishment.

Oak species typically have the greatest survival in direct seeding programs (Table 2) and perform well when compared to planted seedlings. For example, there was no significant difference in survival between direct seeded and planted seedlings of Quercus ilex when planted in harsh conditions (Oliet et al. 2015). Survival of direct seeded Quercus species was 34\% compared to 53\% for the recommended planted seedling stocktype in Mediterranean conditions (González-Rodríguez et al. 2011). In long term field trials (5-6 years) planting of oak seedlings resulted in $91 \%$ to $65 \%$ survival, while direct seeded seedlings had 56 to 53\% survival (Zaczek et al. 1997; Valkonen 2008).

Seedlings established from direct seeding typically have slower growth compared with planted seedlings. In a four year field trial of Pinus sylvestris planted seedlings, initially greater in size, maintained a greater size and higher growth rate resulting in directed seeded seedlings being $50 \%$ smaller (Figure 8 ). Similarly, other studies showed planted seedlings had higher average height growth than direct seeded seedlings (Noble 1985) and direct seeded seedlings were $40 \%$ to $50 \%$ smaller than planted seedlings after four years in the field (Allen 1990; Stanturf and Kennedy 1996; Fleming et al. 2001; Parker et al. 2001; Pausas et al. 2004; Valkonen 2008). For Quercus rubra, only $12 \%$ of direct seeded seedlings exceeded the plantation mean height, based on container-grown planted seedlings, after three years (Zaczek et al. 1997). For temperate hardwood and conifer species growth differences between direct seeded and planted seedlings extended well into stand development with planted seedlings still greater in size five (Stanturf et al. 2009), ten (Smith et al. 1968; Densmore et al. 1999), 11 (Ackzell 1993), 15 (Haywood and Barnett 1994) and 17 years (Sharapov 1931, cited in Ivkov 1971) after stand establishment indicating that direct seeded seedlings grow slower in the field if they are smaller initially.

If direct-seeded seedlings are of a comparable size to planted seedlings after initial field establishment they can have the same or better growth rates. In a nine-year study comparing direct-seeded and planted seedlings of Fagus sylvatica, only the most dominant direct seeded seedling had comparable stem diameter or greater height growth than the overall population of $1+0$ planted seedlings (Ammer and El Kateb 2007; Ammer and Mosandl 2007), whereas the overall population of 2+0 seedlings (i.e. larger at planting) had better growth (Ammer and Mosandl 2007). In another study, direct seeded Quercus faciata var. pagodaefolia, reached the same height and diameter of planted seedlings after five years at the field (Mullins et al. 1997). Stands of Pinus concorta established by direct seeding initially grew more slowly than planted stands, 
but actually grew faster once they reach a dominant height of 13-14 meters (Backlund and Bergsten 2012; Ahnlund Ulvcrona et al. 2013).

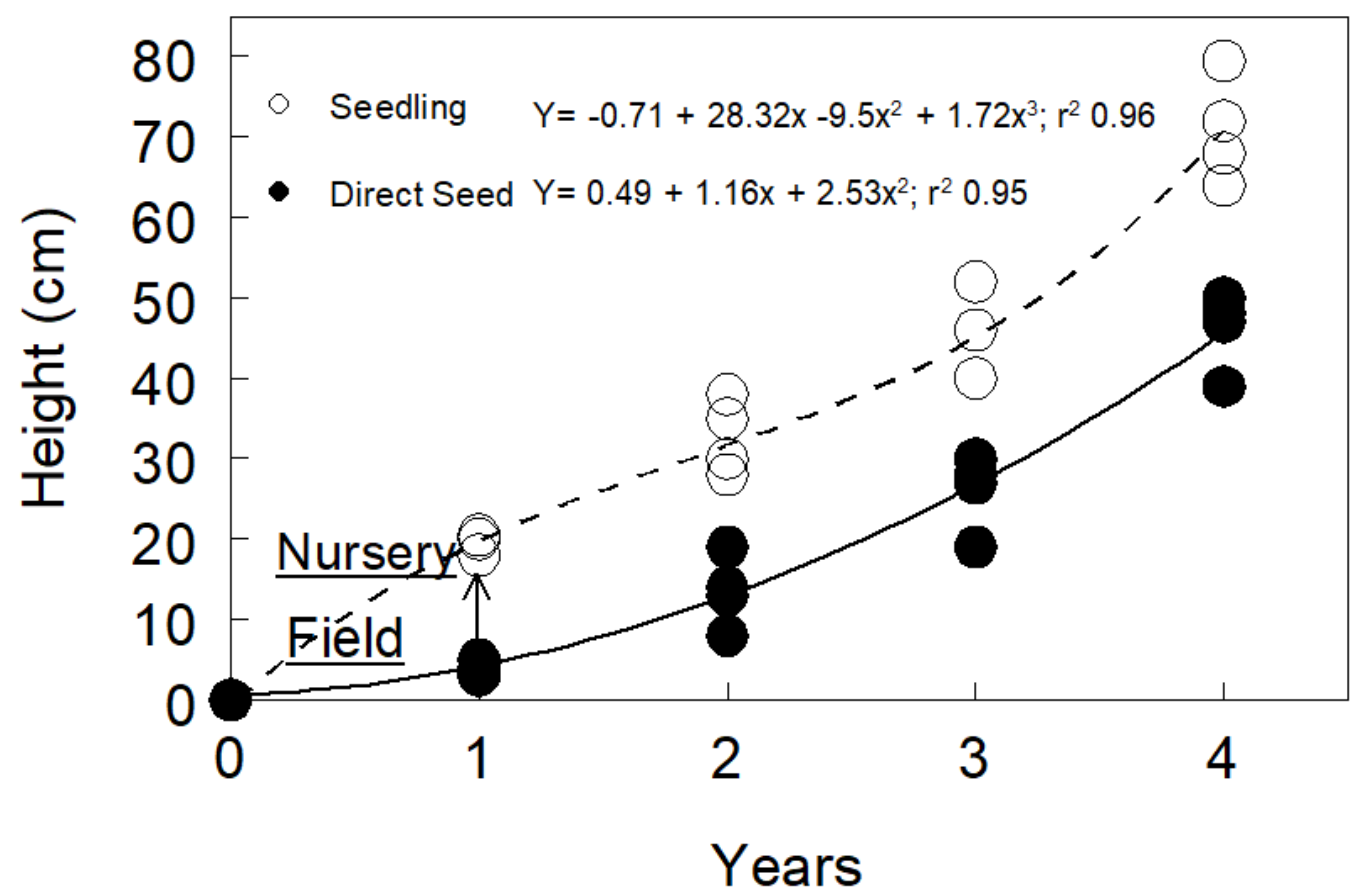

Figure 8. Shoot height development of seedlings and direct seeded Pinus sylvestris from multiple seed sources (adapted from Wennström et al. 2007). Height growth during the first year occurred either in the nursery or on the field site. Nursery grown seedlings were planted at the end of year one on the same site as direct seeded seedlings (arrow notes their field planting date).

Regeneration silvicultural practices, such as direct seeding or planting seedlings, provide a means for directing the course of the secondary forest successional process on restoration sites through the addition of desirable plant species (Grossnickle 2000), and the removal or suppression of undesirable plant species (Wagner and Zasada 1991). Site preparation or vegetation management practices can alleviate site resource competition, but this reduction in vegetative competition is ephemeral, meaning that seedlings need to be large enough to capture site resources and maintain growth that exceeds reinvasion of the site by plant competition. Studies have shown that planted seedlings with a larger shoot and root systems can have greater survival (Grossnickle 2012) and keep their size advantage over time (Grossnickle and MacDonald 2017) on sites with competing vegetation. To be a successful restoration option, direct seeding needs to establish seedlings that grow quickly and become large enough to capture site resources. 


\section{Operational Direct Seeding Practices}

Since the 1970s, the use of direct seeding has declined to the point that it is now only a marginal component of forest restoration programs in most developed countries. For example, in Canada it is used in only in $3 \%$ of forest regeneration programs, with Ontario having the largest program at $13 \%$ of their reforestation program (Natural Resources Canada 2014). In the United States the last reported statistics (i.e. 1996), showed only 8,516 ha (less than $1 \%$ of all planting) were direct seeded (Moulton 1999). Currently, the amount of acreage direct seeded in the United States is so small that there are no available statistics on this practice (Hernandez, personal communication). In Europe, the few countries that report direct seeding information show a low (Sweden 5\% - Ersson 2014); Serbia 15\% (Ivetić, unpublished data)) to a moderate (Finland 22\% (Finnish Statistical Yearbook of Forestry 2014)) amount of restoration acreage applying this practice. In northern and northwestern Russia, 43\% of total artificial regeneration in 2002 was done by direct seeding (Leinonen et al. 2008). Application of direct seeding is said to be on a much larger scale in tropics, e.g. China and Vietnam (Schmidt 2008), and India (Pandey and Prakash 2014). From 1952 to 2008 a total of 30.7 million hectares was aerial seeded in China (Cao et al. 2011), with 136,400 ha in year 2012 (The National Forestry Bureau 2013).

\subsection{Reasons for the Limited Use of Direct Seeding}

Reasons for the limited use of direct seeding in developed countries can be attributed to a number of factors.

\section{Required stocking of the site}

Many operational reforestation programs require full site occupancy of desired tree species to be considered fully stocked with a defined criterion for number of saplings of a certain size within a given timeframe so the site is free-to-grow and no further regeneration silvicultural practices are required. Also, many forest industry programs have moved into plantation forestry where the even distribution of trees across the site is necessary to maximize stand yield (West 2014). In addition, nearly all levels of government now require proper restocking on any site that has been harvested. The following are examples from across developed countries.

- In North America there are recommended standards for the number of seedlings to be planted at a defined spacing to achieve full stocking of a harvested site (e.g. Oregon (Rose and Haase 2006) and in British Columbia (BC MoF Forest Regulations https://www.for.gov.bc.ca/hfp/silviculture/stocking stds.htm) or to maximize site productivity from the forest plantation (e.g. Southern US - Smith and Strub 1991) within a given timeframe.

- In southern Sweden there are minimal required planting densities of 2,000-4,000 seedlings per hectare for reforestation programs (Holmström et al. 2016).

- In Russia, minimum planting density depends on soil and stock type; 3,000 bareroot seedlings per ha on wet soils to 4,000 bareroot seedlings per ha on dry soils, with these number per hectare decreased to 2,000 (1,000 for container oak transplants) when transplants and containerized seedlings are used (Zhigunov et al. 2014).

- In Serbia, according to Forestry directorate rules the required minimum number of seedlings per hectare depends on species: for Populus sp. - 300, for Prunus avium and Juglans regia - 500, and 2,000 for transplanted seedlings of other species (Forestry Directorate 2016 funding regulations). 
Intensive regeneration silvicultural practices are required to achieve these restocking standards. In many cases, there are restrictions to harvesting adjacent forest stands if the standards are not met. Direct seeding typically has low establishment rates (see Current Direct Seeding Research section) and slower growth rates (see Direct Seeding versus Seedling Comparison section) which results in 'patchiness' in stand establishment, limiting the ability to meet stocking standards within the required timeframe. Direct seeded sites may require an extra investment in planting seedlings to achieve adequate stocking (Kankaanhuhta and Saksa 2013). This difficulty for direct seeding to achieve stocking standards influences forest regeneration decisions towards planting seedlings.

\section{Increased use of high quality seed}

In many developed countries high-quality seed is used in reforestation programs. The following are some examples.

- In the Nordic region the use of improved seed from seed orchards has increased in recent years with 94-99\% of Picea abies and Pinus sylvestris seedlings originating from seed orchards in Sweden, Finland and Norway (Rytter et al. 2016).

- In Great Britain 75\%, and in Denmark $90 \%$ of Picea stichensis seed comes from seed orchards (Lee et al. 2013).

- In the Pacific Northwestern US, much of the Peudotsuga menziesii and Tsuga heterophylla seed, as well as nine "minor" conifer species used for reforestation on industrial and some public forest lands are produced in seed (Miller and DeBell 2013).

- In British Columbia Canada, select seed is used for $65 \%$ of the total provincial annual seeding of 245 million seedlings (Forest Genetics Council of BC 2016).

- In the Southeastern US $100 \%$ of Pinus taeda and Pinus elliottii seed comes from seed orchards ( $1^{\text {st }}$ through $3^{\text {rd }}$ generation) to produce 850 million seedlings (South et al. 2016).

As tree improvement programs start to produce $1^{\text {st }}$ to $3^{\text {rd }}$ generation seed, the cost does not make it a viable option for direct seeding programs. For example, in British Columbia Canada the seed, for all tree species, used in the provincial seeding program typically has a germination capacity of $>85 \%$ (Kolotelo personal communication). It becomes more logical to use this high-quality seed in seedling production programs where $>90 \%$ of the seed is turned into plantable seedlings when grown in nursery programs under controlled environmental conditions (Landis et al. 1998) compared to the low conversion rates that typically occur in direct-seeding programs (see Current Direct Seeding Research section).

For over 50 years, foresters have recognized quality seedlings are central to any successful forest restoration program (Wakeley 1954; Duryea 1985; Rose et al. 1990; Colombo and Nolan 1997; Grossnickle 2000; Riley et al. 2010). Since the mid-20 $0^{\text {th }}$ century an extensive amount of effort has gone into nursery cultural practices that improve seedling quality, which has translated into improved seedling survival (Grossnickle 2012) and growth (Grossnickle and MacDonald 2017) after planting in restoration programs around the world. The use of high quality seedlings can increase chances of successful seedling and forest stand establishment. 


\section{Time lag in seedling development}

Seedlings produced from direct seeding compared to planted seedlings have slower development (i.e. reduced size) on the reforestation site (see Seedling Comparison section).

\section{Operational Performance}

Operational direct seeding programs show a range of results, from total failures to success (Table 3). In over one-half of these programs the final stocking rate did not meet management objectives. Reasons given for not meeting the program objective were similar to those described above (see Factors Affecting Conversion Rates section). For Pinus massoniana direct seeding was considered successful because stand development after age 21 was similar to natural regeneration (Xiao et al. 2015), while direct seeding of Cedrus atlantica was considered a success because it improved the site by establishing a forest stand (du Cross et al. 2004). Partial success occurred with Pinus tabulaeformis because direct seeding resulted in higher stand density, but lower growth rate, compared to seedling planting (Li et al. 2009). Ultimately one must define what is meant by reforestation success. If successful forest site restoration is defined as a fully stocked stand, then direct seeding needs to achieve at least an $80 \%$ restocking of the site to be a less expensive option than planting seedlings (Mitchell et al. 1991).

Table 3. Operational application of direct seeding in restoration programs and the reported program success result.

\begin{tabular}{|c|c|c|c|c|c|}
\hline Program type & Species & Country & Application ( ${ }^{1}$ & $\begin{array}{l}\text { Operational } \\
\text { Result ( }\end{array}$ & Source \\
\hline \multirow{6}{*}{$\begin{array}{l}\text { Reforestation } \\
\text { sites }\end{array}$} & Picea mariana & Canada & SS & $\mathrm{F}$ & Fraser 1981 \\
\hline & $\begin{array}{l}\text { Betula pendula and } B . \\
\text { pubescens }\end{array}$ & $\begin{array}{l}\text { Great } \\
\text { Britain }\end{array}$ & GB & $\mathrm{F}$ & Willoughby et al. 2007 \\
\hline & Pinus tabulaeformis & China & $A B$ & $P$ & Li et al. 2009 \\
\hline & Pinus elliottii & USA & SS & $\mathrm{S}$ & Barnett 2011 \\
\hline & Various species & Brasil & GB & $\mathrm{S}$ & Campos Filho et al. 2014 \\
\hline & Pinus massoniana & China & $A B$ & $\mathrm{~S}$ & Xiao et al. 2015 \\
\hline \multirow{4}{*}{$\begin{array}{l}\text { Post-fire } \\
\text { reforestation } \\
\text { sites }\end{array}$} & Various species & USA & SS & $\mathrm{F}$ & Wahlenberg 1925 \\
\hline & Various species & $\begin{array}{l}\text { New } \\
\text { Zealand }\end{array}$ & GB & $P$ & Ledgard and Davis 2004 \\
\hline & $\begin{array}{l}\text { Enterolobium } \\
\text { cyclocarpum }\end{array}$ & Mexico & AS & $\mathrm{F}$ & Garcia Cuevas et al. 2010 \\
\hline & Eucalyptus delegatensis & Australia & $A B$ & $\mathrm{~S}$ & Bassett et al. 2015 \\
\hline \multirow[t]{5}{*}{$\begin{array}{l}\text { Afforestation } \\
\text { Sites }\end{array}$} & $\begin{array}{c}\text { Pinus nigra and } P \text {. } \\
\text { sylvestris }\end{array}$ & Serbia & SS & $\mathrm{S}$ & Stamenković et al. 1994 \\
\hline & Various species & USA & SS & $\mathrm{S}$ & Stanturf et al. 1998 \\
\hline & Cedrus atlantica & France & GB & $\mathrm{S}$ & Du Cros et al. 2004 \\
\hline & Various species & Laos & GB and SS & $P$ & Sovu et al. 2010 \\
\hline & Various species & China & $A B$ & $P$ & Cao et al. 2011 \\
\hline
\end{tabular}

1) SS - Spot seeding, GB - Ground broadcast, AB - Aerial broadcast

2) $\mathrm{S}$ - success in most cases is defined by high or at least acceptable (by the forest authority) stocking rate, $\mathrm{P}$ - partial indicates some successful seedling establishment, F - failure is defined as low survival and establishment rate, and ultimately by low stocking rate; as defined in the citations. 


\subsection{Direct Seedling - Recommended Seeding Rates}

Seedbed Receptivity

Seed Dispersion

Seeding Rate
Reforestation through direct seeding is applicable under conditions where seeds of woody plants can germinate and establish rapidly in response to vegetative competition (Schmidt 2008) and harsh environments (Chik 2004). The ability to stock the site through direct seeding is dictated by a number of factors defining program success.

The term seedbed receptivity is defined as the number of ideal seeding microsites and the ability to deliver seed to those sites (Fleming et al. 2001). Seedbed receptivity can be expressed by the establishment ratio (i.e., number of established seedlings divided by the number of sown seeds), with this ratio dictated by species and site conditions (Groot 1994). The relationship between stocking percentage and seedbed receptivity is site limited because not all locations on a site are receptive. For example, in an assessment of 20 seedbed types, the establishment ratio ranged for $0.1 \%$ to $54 \%$; with sheared flat surface of poorly decomposed peat being the most receptive site (Groot 1988).

Silvicultural practices are intended to improve site conditions and receptivity by reducing or rearranging slash, ameliorating adverse forest floor, soil, above- and belowground vegetation structure, or modifying other site biotic factors (Daniel et al. 1979). Seedbed receptivity for direct seeding can be managed through silvicultural practices that expose more of the site to the optimum seed to seedling establishment pathway.

How seed is spread across the restoration site is a critical step in ensure a fully stocked site (Groot 1988). Highest stocking rates are achieved when seed is uniformly spread across the site, though typical broadcast seeding practices usually results in a non-uniform distribution pattern (Figure 1B). This uneven seed distribution can be made up, in part, by ensuring there are enough receptive seedbed sites and increasing the seeding rate. The combination of seedbed receptivity and seed distribution dictates why furrow/line or spot seeding requires a lower seeding rate than broadcast seeding (Table 4) because these practices are more effective at distributing seeds to receptive seedbed sites.

The seeding rate is the most easily controlled variable in direct seeding systems. However, Groot (1988) warns that managers need to avoid merely increasing the seeding rate to try and achieve their stocking objective. For example, the amount of seed needed to achieve site stocking initially increases dramatically with seeding rate (up to 200,000 seeds to achieve $50 \%-60 \%$ stocking), with further amounts of seed resulting in a minimal increase in stocking levels (i.e. a diminishing benefit of additional amounts of seed), and never reaching full stocking (Figure 9). Seeding rate is a less important factor once the quantity sown is above a certain threshold (Farrelly et al. 2003) because limitations of seedbed receptivity cannot be overcome by just increasing the seeding rate. 


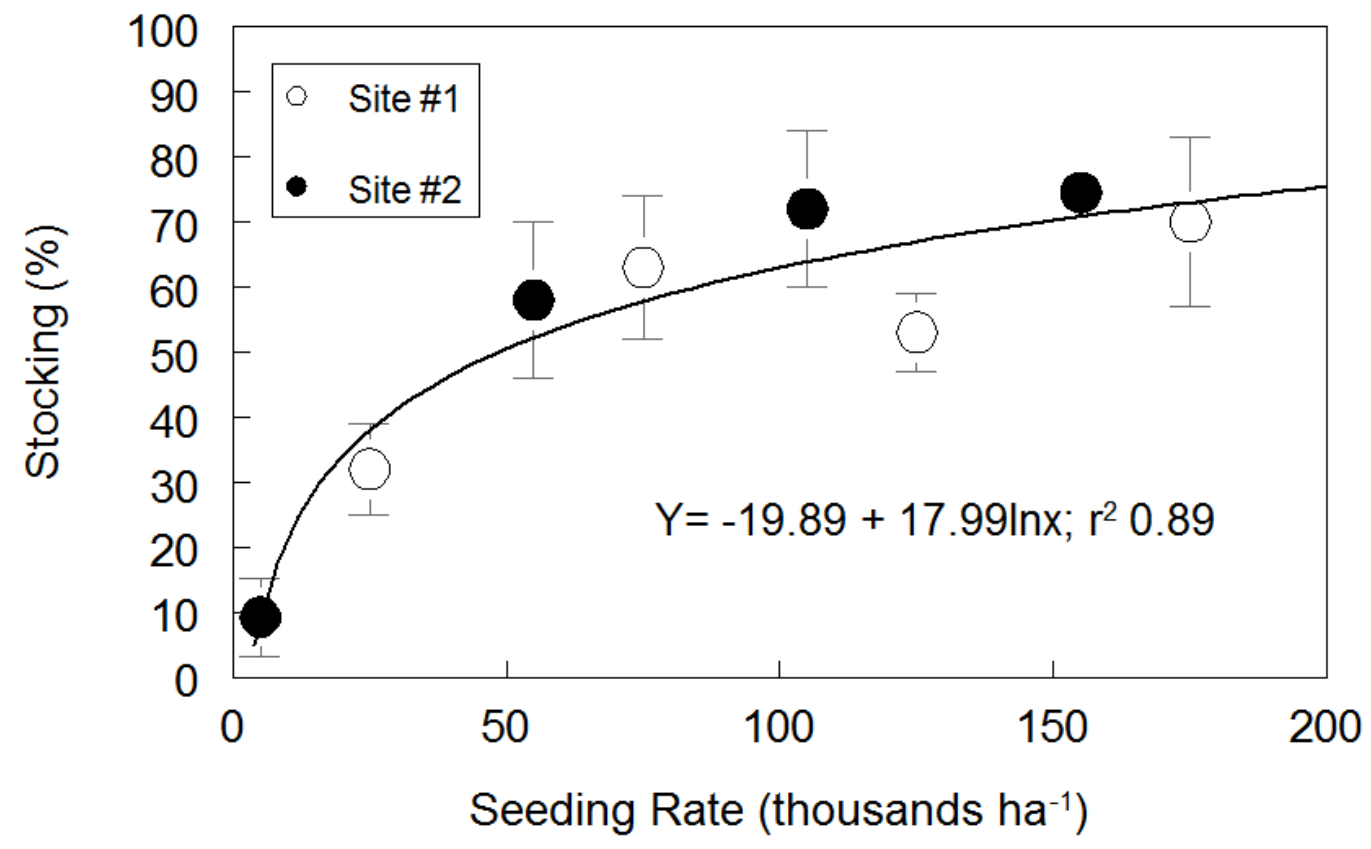

Figure 9. Stocking after five years (i.e. portion of quadrats stocked with at least one seedling) for Picea mariana across two boreal restoration sites with various broadcast seeding rates (adapted from Groot 1988).

\section{Operational Seeding Rates}

A number of developed countries have defined recommended direct seeding rates that are required to ensure a fully stocked stand in forest restoration programs across a wide range forest sites (Table 4). These seeding rates are high due to the low expected conversion rates (see Conversion Rates section). For example, Pinus sylvestris operational trials found the initial seedling establishment was normally between 10 and $20 \%$ even at rates of $50,000-60,000$ seeds ha $^{-1}$ (Helenius 2016). Trials conducted in Sweden found that to obtain a density of 5,000 stems ha $^{-1}$ four years after seeding, 61,000 viable stand seeds ha ${ }^{-1}$ or 41,000 orchard seeds ha ${ }^{-1}$ were required if microsite preparation was not used (Wennström et al. 1999). Site scarification to the mineral soil and microsite preparation reduced seeding requirements to 32,000 stand seeds or 22,000 orchard seeds ha-1 (Wennström et al. 1999). Recommended seeding rates for hardwoods in the central United States is 7,500 ha-1 for drill seeding and $11,250 \mathrm{ha}^{-1}$ for broadcast seeding (National Resources Conservation Services 2015). Interestingly, recommended direct seeding rates for oaks is quite low, with a seeding rate of 1,000 acorns ha ${ }^{-1}$ for restoring open oak woodlands in Mediterranean ecosystems (SánchezGonzález et al. 2016) and 2,000 to $4,000 \mathrm{ha}^{-1}$ in marginal agricultural land in the lower Mississippi river alluvial valley (Stanturf et al 1998). However, direct seeding rates of oaks need to be 9 to 4.5 times greater for direct seeding through broadcast $\left(6,500 \mathrm{ha}^{-1}\right)$ or drill seeding $\left(3,250 \mathrm{ha}^{-1}\right)$ respectively, to achieve same the stand density of planted seedlings $\left(730 \mathrm{ha}^{-1}\right)$ (Lockhart et al. 2003). The lower seeding rate for oak species is probably dictated by having a relatively high establishment success rate (Table 2 ). 
Table 4. Recommended operational direct seeding rates for a number of developed countries under various direct seeding practices.

\begin{tabular}{|c|c|c|c|}
\hline \multicolumn{4}{|c|}{ Seeding Rate (Seeds ha-1 $)$} \\
\hline Species & Broadcast & Furrows/Line & Spot \\
\hline \multicolumn{4}{|c|}{ Pacific Northwest of North America $^{(1}$} \\
\hline Pseudotsuga menziesii & $50,000-70,000$ & $12,000-16,000$ & 20.000 \\
\hline Pinus ponderosa & 18,000 & 10,000 & 15.000 \\
\hline Larix occidentalis & $90,000-140,000$ & $16,000-24,000$ & 21.000 \\
\hline \multicolumn{4}{|c|}{ Western Boreal Forests of Canada ${ }^{(1}$} \\
\hline Interior spruce & $100,000-200,000$ & $20,000-24,000$ & 21.000 \\
\hline Pinus contorta & $70,000-80,000$ & 16,000 & 15.000 \\
\hline \multicolumn{4}{|c|}{ Eastern Boreal Forests of Canada ${ }^{12}$} \\
\hline Pinus banksiana & $25,000-100,000$ & $15,000-30,000$ & $15.000-30.000$ \\
\hline Picea mariana & $100,000-300,000$ & & \\
\hline \multicolumn{4}{|c|}{ Southeastern Forests of the United States ${ }^{3}$} \\
\hline Pinus taeda & 30,000 & 5,300 & 9.000 \\
\hline Pinus palustris & 37,000 & 7,200 & 10.750 \\
\hline Pinus elliottii & 35,000 & 7,200 & 10.750 \\
\hline Pinus echinata & 49,000 & 10,750 & 14.300 \\
\hline \multicolumn{4}{|c|}{ United Kingdom ${ }^{(4}$} \\
\hline Fraxinus excelsior & 200,000 & & \\
\hline Quercus robur & 100,000 & & \\
\hline Betula pendula & 200,000 & & \\
\hline Acer pseudoplatanus & 200,000 & & \\
\hline Prunus avium & 200,000 & & \\
\hline \multicolumn{4}{|c|}{ Finland $^{(5}$} \\
\hline Pinus sylvestris & & 50,000 & 60,000 \\
\hline
\end{tabular}

\section{Potential Alternative Direct Seeding Practices}

Improvements in the application of direct seeding for forest restoration programs requires better ways to create more effective seed dispersion, increase seedbed receptivity, minimize seed predation or create a more favorable microsite environment. In addition, seed enhancement technologies should be examined. These technologies apply seed coating to deliver materials such as nutrients, microbial inoculants and protection agents or hydration treatments to the seed that can enhance germination, emergence, and/or early seedling growth. Existing seed enhancement technologies used in agriculture and horticulture (reviewed by Halmer 2006) and other disturbed ecosystems (reviewed by Madsen et al. 2016) to enhance seed establishment success could provide useful options. The following are examples of proposed technology to increase direct seeding effectiveness for forest regeneration programs.

Seed Shelters

The function of seed shelters is twofold. First, seed shelters can modify the environment around the seed. Studies have found seed shelters can create a positive environment for the seed (i.e. decreases incoming solar radiation) (Kjelgren 1994; Bergez and Dupraz 1997; Bellot et al. 2002) (i.e. reduced vapor pressure deficit and wind speed) (Bergez and Dupraz 1997). Shelters can also have potential for negative effects on the growing environment (i.e. increase the temperature and vapor pressure deficit) 
(Kjelgren 1994; Bellot et al. 2002) resulting in summertime conditions that can cause photoinhibition to seedling in shelters (Pemán et al. 2009).

Second, seed shelters can provide protection from predators (Caccia and Ballaré 1998; Fleming et al. 2001; Pausas et al.2004; Reque and Martin 2015). Direct seeding performance with seed shelters is reported in a number of studies. In one study seed shelters successfully promoted seed germination ( $1 \%-12 \%$ unprotected vs. $77 \%-84 \%$ protected) and seedling survival ( $1 \%-10 \%$ unprotected vs. $54 \%-74 \%$ protected) (Barton et al. 2015). Other studies have also reported increased seedling establishment with seed shelters (Caccia and Ballaré 1998; Densmore et al. 1999; Fleming et al. 2001; Pauses et al. 2004; Petursson and Sigurgeirsson 2004, Madsen and Löf 2005; Valkonen 2008; Castro et al. 2015; Repáč et al. 2017), though not under all field conditions (DeLong et al. 1997; Pausas et al. 2004). Seed shelters have also resulted in greater seedling growth (Pausas et al. 2004). In a literature review Ceccon et al. (2016) found that seed protection increased the probability of successful seed germination, though there was no benefit during seedling growth. Figure 10 (A, B and C) shows examples of seed shelters for direct seeding programs. Even if seed shelters increase success, however their use complicates the process of seeding and increases planting costs, thereby diminishing one of the biggest advantages of direct seeding compared to planting seedlings.

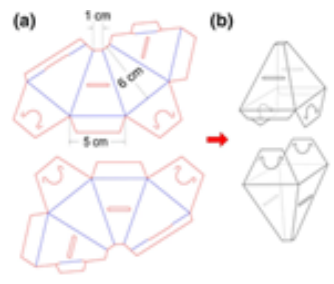

(c)

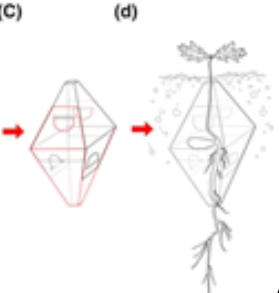

(A)

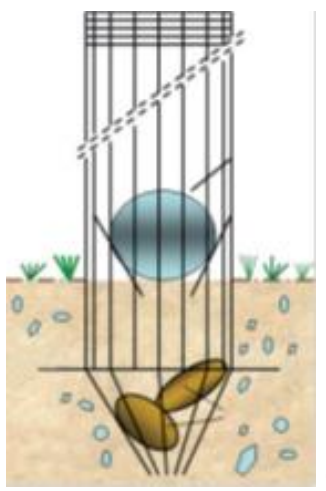

(B)

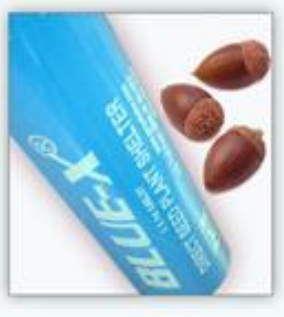

(C)
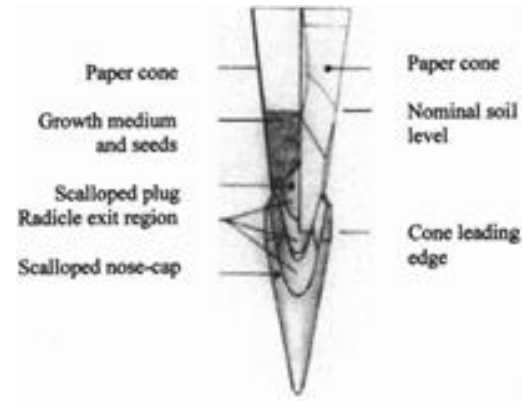

(D)

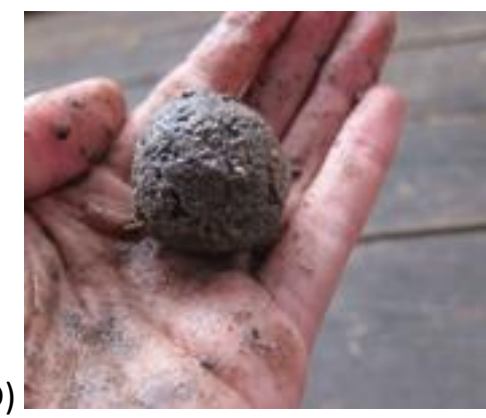

(E)

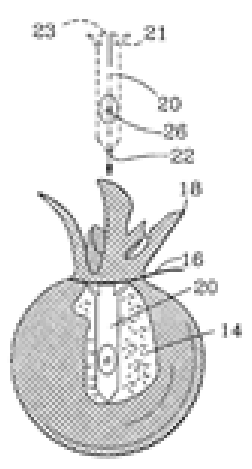

$(\mathrm{F})$

Figure 10. Examples of alternative practices for the application of direct seeding through the use of seed shelters: A) (Castro et al. 2015); B) Reque and Martin (2015); C) The BLUE- $X^{\otimes}$ Direct Seed Plant Shelter

(http://www.growtube.com/products/directseed/); or various delivery systems for aerial seeding: D) aerial dart seed delivery system (Wood 1984); E) a seed bomb (Ortolani et al. 2015); F) biodegradable seed pouch system (Fima 2003). 


\section{Hydro Seeding}

An improved version of simply dropping the seed from the aircraft is hydro seeding or hydromulching. Hydro seeding was developed in the 1950s, and is a technique for distributing seeds in a slurry form combined with processed woodchip fibers and other optional enhancements, such as fertilizer and a tackifying agent (Schiechtl 1980; Becker 2001). Ideally hydro seeding creates a thin layer covering the seed; much like covering seed with topsoil, thereby improving seed germination (Schiechtl 1980). This technique is an effective seeding approach on steep and rocky slopes that are hard to seed or plant with seedlings. The main drawbacks of hydro seeding are the potential rapid deterioration of the cover layer under extreme weather conditions thereby exposing seed prior to germination (Schiechtl 1980) and the requirement for a large amount of water to create the slurry (i.e. low seed to cargo weight ratio) (Becker 2001). Hydro seeding also requires heavy equipment that is not easily moved through rough terrain. Hydro seeding is best used in programs where there is rapid access to a water source and a road system for ease of moving heavy equipment.

\section{Alternative Aerial Direct Seeding Options}

Aerial seeding of reforestation sites has been ongoing for decades. For example, in Canada aerial direct seeding was a main form of reforestation (i.e. fixed wing aircraft or helicopters) used in the 1960 s and 1970 s for $~ 50 \%$ of the total area seeded (Waldron 1973). Although aerial seeding is not a new concept, new aerial seeding application technologies have been developed for restoration programs as described below.

\section{Seed Bundles}

Seeds are put into packages where they are combined with various materials that are intended to benefit the seed after being distributed across the site. These seed bundles come in various forms.

- A seed-containing aerial dart (Figure 10D) serve as ground-penetrating containers for seeds (Wood 1984) (Figure 10D). Testing found that the best seed germination rates $(45 \%)$ and survival rate ( $27 \%$ after $1 \mathrm{yr}$ ) occurred when seeds ended up being planted $1 \mathrm{~cm}$ below the soil surface (Wood 2000).

- Aerial seed bombs are made from various substances as a way to deliver multiple seeds. In its most basic form these seed bombs are made with a clay shell (Figure $10 \mathrm{E})$, which could also contain nutrients, chemicals to deter seed predators, symbiotic microbes and hydrogels (Ortolani et al. 2015). Experiments with seed bombs have been carried out with Pinus sylvestris seeds, Quercus ilex, Quercus suber and Myrtus communis (Ortolani et al. 2015). A similar version of this system is being used by the Thai government to reforest disturbed areas (https://youtu.be/IpN9-45XPrs). Trials have yet to define plant establishment success.

- Airborne seed pouches have the ability to partially penetrate the ground when delivered by an aerial system (Fima 2003). The pouch is a small biodegradable package containing seeds, along with soil and nutrients (Figure 10F). The pouch, spherical or conical in shape, includes a flared open end formed by constricting the skin to allow for a relatively slow descent when delivered by low flying aerial system. Additionally, there is an elongated vertical shaft to assist in orientation when dropped, to facilitate penetration into the ground and to release the package contents on impact. 
- Pasta seed pillows are made up of Diatomaceous earth, bentonite clay, compost and worm castings. The nickel-sized pods contain native seeds, a special mix of plant nutrients and hydrogel. Controlled laboratory trials show improved performance over direct seeding with bare seed (Madsen et al. 2016).

Drones

Recent technological advances in unmanned aerial vehicles (or drones) and imaging systems raise the possibility of automating several of restoration tasks (Elliott 2016). Drones and new imaging devices have the potential to conduct site monitoring (i.e. assess site regeneration potential, plan interventions and assess progress), aerial seeding and vegetation management. There are a number of private companies using drones for addressing site management issues and to apply aerial seeding of restoration sites (BioCarbon Engineering - www.biocarbonengineering.com/; Droneseed www.droneseed.co). Their intent is to map sites to define specific microsites that have the best chance for seed establishment, and then deliver seeds packets to these microsites, and follow-up with monitoring direct seeding success and applying precision spot spraying of herbicides for site vegetation management practices.

\section{Conclusions}

Direct seeding has the potential to address worldwide forest restoration programs. A major benefit of this option is that it can be done quickly, over large disturbed areas and at a relatively low cost. It also has the potential to create ecologically diverse forest stands that have a more natural root system form. However, direct seeding has low seedling establishment rates (i.e. typically around $20 \%$ ) due to seeding practices, site conditions, seed predation and vegetation competition. In addition, seedlings established through direct seeding grow slower than planted seedlings, thus requiring additional silvicultural practices to ensure establishment of the desired forest stand. This is why the use of direct seeding as the sole means to achieve successful regeneration, without the inclusion of a seedling planting option, has been debated over the last century (i.e. from Toumey 1916 to Ceccon et al. 2016).

To be effective better practices are required to improve the success of direct seeding programs. It is important to recognize that successful forest restoration with direct seeding is more than just seed delivery to the site; it is a comprehensive process requiring many silvicultural factors to ensure program success. First, planning for the application of direct seeding, one needs to consider that seedbed receptivity and seed dispersion are just as important as seeding rate. Second a number of silvicultural practices need to be considered including: seed quality to ensure maximum conversion, timing of seeding and seeding practices for maximizing germination of the sown species, controlling seed predation, optimizing microsite environmental conditions and managing competitive vegetation. Ultimately, any determination of regeneration program success needs to consider all practices that are required to achieve a fully established forest stand. Even controlling these silvicultural practices does not guarantee a successful program, but by applying best practices one increases chances for improved success of direct seeding on forest restoration sites. 


\section{References}

Ackzell L (1993) A comparison of planting, sowing and natural regeneration for Pinus sylvestris (L.) in boreal Sweden. Forest Ecology and Management 61(3-4): 229-245.

https://doi.org/10.1016/0378-1127(93)90204-Z

Adams MJ, Groot A, Crook GW, Fleming RL, Foreman FF (2005) Direct Seeding Black Spruce and Jack Pine: A Field Guide for Northern Ontario. Can. For. Serv., Sault Ste Marie, Canada. 254 p.

Ahnlund Ulvcrona K, Karlsson L, Backlund I, Bergsten U (2013) Comparison of silvicultural regimes of lodgepole pine (Pinus contorta) in Sweden 5 years after precommercial thinning. Silva Fennica 47 (3) article id $974.17 \mathrm{p}$.

Ahtikoski A, Pulkkinen P (2003) Cost-benefit analysis of using orchard or stand seed in Scots pine sowing, the case of northern Finland. New Forests 26: 247p. https://doi.org/10.1023/A:1024423719864

Allen JA (1990) Establishment of bottomland oak plantations on the Yazoo National Wildlife Refuge Complex. Southern Journal of Applied Forestry 14: 206-210.

Ammer C, El Kateb H (2007) Buchensaat oder -pflanzung: Vergleich zweier Optionen zum Umbau von Fichtenreinbeständen. LWF-Bericht 58: 38-41.

Ammer C, Mosandl R (2007) Which grow better under the canopy of Norway spruce planted or sown seedlings of European beech? Forestry 80: 385-390. https://doi.org/10.1093/forestry/cpm023

Ammer C, Mosandl R, Kateb HE (2002) Direct seeding of beech (Fagus Sylvatica L.) in Norway spruce (Picea abies [L.] Karst.) stands - effects of canopy density and fine root biomass on seed germination. For. Ecol Manage. 159: 59-72. https://doi.org/10.1016/S0378-1127(01)00710-1

Ammondt SA, Litton CM, Ellsworth LM, and Leary JK (2013) Restoration of native plant communities in a Hawaiian dry lowland ecosystem dominated by the invasive grass Megathyrsus maximus. Applied Vegetation Science, 16(1), 29-39. https://doi.org/10.1111/i.1654-109X.2012.01208.x

Anonymous (2017) The State of Canada's Forests. Ministry of Natural Resources. Ottawa, ISSN 1488-3766. $92 \mathrm{p}$.

Atondo-Bueno EJ, López-Barrera F, Bonilla-Moheno, M., Williams-Linera, G., Ramírez, N. 2016. Direct seeding of Oreomunnea mexicana, a threatened tree species from Southeastern Mexico. New Forests 47:845-860. https://doi.org/10.1007/s11056-016-9548-2

Avendaño-Yáñez ML, Sánchez-Velásquez LR, Meave JA, Pineda-López MR (2014) Is facilitation a promising strategy for cloud forest restoration? For Ecol Manag 329:328-333.

Avendaño-Yáñez ML, Sánchez-Velásquez LR, Meave JA, Pineda-López MR (2016) Can Pinus plantations facilitate reintroduction of endangered cloud forest species? Landsc Ecol Eng 12: 99-104. https://doi.org/10.1007/s11355-015-0277-z

Backlund I, Bergsten U (2012) Biomass production of dense direct-seeded lodgepole pine(Pinus contorta) at short rotation periods. Silva Fennica 46(4): 609-623. https://doi.org/10.14214/sf.914

Balandier P, Prévosto B (2016) Forest restoration in the French Massif Central Mountains. In:Stanturf JA (ed). Restoration of Boreal and Temperate Forests, $2^{\text {nd }}$ Edition. CRC Press, Boca Raton FL, 337354.

Balandier P, Frochot H, Sourisseau A (2009) Improvement of direct tree seeding with cover crops in afforestation: microclimate and resource availability induced by vegetation composition. Forest Ecology and Management 257: 1716-1724. https://doi.org/10.1016/i.foreco.2009.01.032

Balisky AC, Salonius P, Walli C, Brinkman D (1995) Seedling roots and forest floor: misplaced and neglected aspects of British Columbia's reforestation effort? For. Chron. 71: 59-65. https://doi.org/10.5558/tfc71059-1

Barnett JP (2014) Direct Seeding Southern Pines: Development of Techniques, Use, and Current Status. Tree Planters' Notes 57: 35-58.

Barnett JP, Baker JB (1991) Regeneration methods. In: Duryea ML, Dougherty PM (eds) Forest regeneration manual. Kluwer Academic Publishers, Dordrecht, The Netherlands 35-50. https://doi.org/10.1007/978-94-011-3800-0 3

Barnett JP, (1998) Oleoresin capsicum has potential as a rodent repellent in direct seeding longleaf pine. In Waldrop, T.A., ed. Proceedings of the ninth biennial southern silvicultural research conference. 
Gen. Tech. Rep. SRS-20. Asheville, NC: U.S. Department of Agriculture, Forest Service, Southern Research Station: 326-328.

Barnett JP, James P (2011) Faces from the past: profiles of those who led restoration of the South's forests. Gen. Tech. Rep. SRS-133. Asheville, NC: U.S. Department of Agriculture, Forest Service, Southern Research Station. 68 p.

Barron P, Dalton G (1996) Direct seeding of native trees and shrubs in coastal environments. Journal of coastal research, 1006-1008.

Barton C, Miller J, Sena K, Angel P, French M (2015) "Evaluating the Use of Tree Shelters for Direct Seeding of Castanea on a Surface Mine in Appalachia." Forests 6, no. 10: 3514-3527. https://doi.org/10.3390/f6103514

Bassett OD, Prior LD, Slijkerman CM, Jamieson D, Bowman DMJS (2015) Aerial sowing stopped the loss of alpine ash (Eucalyptus delegatensis) forests burnt by three short-interval fires in the Alpine National Park, Victoria, Australia. Forest Ecology and Management, 342: 39-48. https://doi.org/10.1016/i.foreco.2015.01.008

Baumhauer H, Madsen P, Stanturf J, (2005) Regeneration by direct seeding - a way to reduce costs of conversion. In: Stanturf, J., Madsen, P. (Eds.), Restoration of Boreal and Temperate Forests. CRC Press, Boca Raton, Florida, 349-354.

Becker R (2001) Effective aerial reseeding methods: market search report. Gen. Tech. Rep. 01511204 SDTDC. San Dimas, CA: U.S. Department of Agriculture, Forest Service, San Dimas Technology and Development Center. $19 \mathrm{p}$.

Bellot J, Ortiz de Urbina JM, Bonet A, Sánchez JR (2002) The effects of treeshelters on the growth of $Q$. coccifera L. seedlings in a semiarid environment. Forestry 75: 89-106.

https://doi.org/10.1093/forestry/75.1.89

Bergez JE, Dupraz C (1997) Transpiration rate of Prunus avium L. seedlings inside an unventilated treeshelter. Forest Ecology and Management, 97(3), 255-264. https://doi.org/10.1016/S03781127(97)00071-6

Birkedal M (2010) Reforestation by direct seeding of beech and oak. Diss. (sammanfattning/summary) Alnarp: Sveriges lantbruksuniv., Acta Universitatis agriculturae Sueciae, 1652-6880; 2010:13 ISBN 978-91-576-7490-6

Birkedal M, Löf M, Olsson GE, Bergsten U (2010) Effects of granivorous rodents on direct seeding of oak and beech in relation to site preparation and sowing date. For Ecol Manag 259: 2382-2389. https://doi.org/10.1016/i.foreco.2010.03.014

Birkedal M, Fischer A, Karlsson M, Löf M, Madsen P (2009) Rodent impact on establishment of directseeded Fagus sylvatica, Quercus robur and Quercus petraea on forest land. Scandinavian Journal of Forest Research, 24(4): 298-307. https://doi.org/10.1080/02827580903055125

Birkedal M, Karlsson M, Löf M, Madsen P (2006) Direct seeding on forestland and the influence of rodent predation on beech nuts. In book of abstracts from IUFRO conference Beech silviculture in Europe's largest beech country. 4 - 8 September 2006, Poiana Brasov, Romania: 21-23. (In press at University of Brasov, Faculty of silviculture and forest engineering)

Bonilla-Moheno M, Holl KD (2010) Direct Seeding to Restore Tropical Mature-Forest Species in Areas of Slash-and-Burn Agriculture. Restor. Ecol.18: 438-445. https://doi.org/10.1111/i.1526100X.2009.00580.x

Brancalion PHS, Schweizer D, Gaudare U, Mangueira JR, Lamonato F, Farah FT (2016) Balancing economic costs and ecological outcomes of passive and active restoration in agricultural landscapes: the case of Brazil. BIOTROPICA 48(6): 856-867. https://doi.org/10.1111/btp.12383

Brofas G, Karetsos G (2002) Revegetation of mining spoils by seeding of woody species on Ghiona mountain, central Greece. Land Degradation and Development, 13: 461- 467. https://doi.org/10.1002/ldr.529

Brooks S, Cordell S, Perry L (2009) Broadcast seeding as a potential tool to reestablish native species in degraded dry forest ecosystems in Hawaii. Ecological Restoration 27: 300-305. https://doi.org/10.3368/er.27.3.300

Bullard SH, Hodges JD, Johnson RL, Straka TJ (1992) Economics of direct seeding and planting for establishing oak stands on old-field sites in the South. South J. Appl.For. 16: 34-40. 
Burdett AN (1990) Physiological processes in plantation establishment and the development of specifications for forest planting stock. Can. J. For. Res. 20: 415-427. https://doi.org/10.1139/x90-059

Cabin RJ, Weller SG, Lorence DH, Cordell S, Hadway LJ (2002) Effects of microsite, water, weeding, and direct seeding on the regeneration of native and alien species within a Hawaiian dry forest preserve. Biol Conserv 104: 181-190. https://doi.org/10.1016/S0006-3207(01)00163-X

Caccia FD, Ballaré CL (1998) Effects of tree cover, understory vegetation, and litter on regeneration of Douglas-fir (Pseudotsuga menziesii) in southwestern Argentina. Can. J. For. Res. 28: 683.692.

Caldicott N (1989) An evaluation of direct seeding in British Columbia, 1989. A report: NandR Forest Management Ltd. $60 \mathrm{p}$.

Camargo JLC, Dorothea I, Ferraz K, Imakawa AM (2002) Rehabilitation of Degraded Areas of Central Amazonia Using Direct Sowing of Forest Tree Seeds. Restor. Ecol 10: 636-644. https://doi.org/10.1046/i.1526-100X.2002.01044.x

Campbell TE (1981) Growth and development of loblolly and slash pines direct-seeded or planted on a cut-over site. South. J. Appl. For. 5, 115-118.

Campos Filho EM, Junqueira RGP, de Sousa OL, Eicholz LL, Marmet CC, da Costa JNMN, Ferreira BD, Alves $\mathrm{HQ}$, Villas-Boas AJA (2014) The Xingu Seed Network and mechanized direct seeding. In: Bozzano, M., Jalonen, R., Thomas, E., Boshier, D., Gallo, L., Cavers, S., Bordács, S., Smith, P. and Loo, J., eds. 2014. Genetic considerations in ecosystem restoration using native tree species. State of the World's Forest Genetic Resources - Thematic Study. Rome, FAO and Bioversity International: 161-164.

Cao S, Chen L, Shankman D, Wang C, Wang X, Zhang H (2011) Excessive reliance on afforestation in China's arid and semi-arid regions: Lessons in ecological restoration. Earth-Science Reviews, 104(4): 240245. https://doi.org/10.1016/j.earscirev.2010.11.002

Castro J, Leverkus AB, Fuster F (2015) A new device to foster oak forest restoration via seed sowing. New Forests 46: 919. https://doi.org/10.1007/s11056-015-9478-4

Ceccon E, González EJ, Martorell C (2016) Is Direct Seeding a Biologically Viable Strategy for Restoring Forest Ecosystems? Evidences from a Meta-analysis. Land Degradation and Development, 27(3): 511-520. https://doi.org/10.1002//dr.2421

Chantal MD, Leinonen K, Ilvesniemi H, Westman CJ (2003) Combined effects of site preparation, soil properties, and sowing date on the establishment of Pinus sylvestris and Picea abies from seeds. Canadian Journal of Forest Research, 33(5): 931-945. https://doi.org/10.1139/x03-011

Chazdon RL (2008) Beyond deforestation: restoring forests and ecosystem services on degraded lands. Science, 320(5882): 1458-1460. https://doi.org/10.1126/science.1155365

Chick H (2004) Direct seeding of native species for reforestation on degraded hillsides in Hong Kong. (Thesis). University of Hong Kong, Pokfulam, Hong Kong SAR. https://doi.org/10.5353/th b3119453

Chrosciewicz Z (1990) Site conditions for jack pine seeding. The Forestry Chronicle, 66(6): 579-584. https://doi.org/10.5558/tfc66579-6

Cole RJ, Holl KD, Keene CL, Zahawi RA (2011) Direct seeding of late-successional trees to restore tropical montane forest. For. Ecol. Manage. 261:1590-1597. https://doi.org/10.1016/i.foreco.2010.06.038

Colombo SJ, Nolan TL (Eds) (1997) Making the grade. New Forest (special issue) 13 (1-3):227-252.

Cornett MW, Puettmann KJ, Reich PB (1998) Canopy type, forest floor, predation, and competition influence conifer seedling emergence and early survival in two Minnesota conifer-deciduous forests. Canadian Journal of Forest Research, 28(2): 196-205. https://doi.org/10.1139/x97-196

Curtis RO, DeBell DS, Harrington CA, Lavender DP, St Clair JB, Tappeiner JC, Walsted JD (1998) Silviculture for multiple objectives in the Douglas-fir region. USDA For. Serv. Gen Tech Rep PNW-GTR-435 https://doi.org/10.2737/PNW-GTR-435

Daniel TW, Helms JA, Baker FS (1979) Principles of Silviculture $2^{\text {nd }}$ Edition, McGraw-Hill, New York.

Davis M, Henley D, Howell C, Coker G (2013) Establishment of Nothofagus solandri var. cliffortioides by seeding in Leptospermum scoparium shrublands. New Zealand Journal of Ecology 37: 139-145. 
de Chantal M , Kuuluvainen T, Lindberg H, Vanha-Majamaa I (2005) Early regeneration of Populus tremula from seed after forest restoration with fire. Scandinavian Journal of Forest Research 20(6): 3342. https://doi.org/10.1080/14004080510040968

de Chantal M, Leinonen K, Ilvesniemi H, Westman CJ, (2004) Effects of site preparation on soil properties and on morphology of Pinus sylvestris and Picea abies seedlings sown at different dates. New Forests 27: 159-173. https://doi.org/10.1023/A:1025042632491

de Souza Gomes Guarino E, Scariot A (2014) Direct seeding of dry forest tree species in abandoned pastures: effects of grass canopy and seed burial on germination. Ecol Res 29:473-482. https://doi.org/10.1007/s11284-014-1143-4

DeLong HB, Lieffers VJ, Blenis PV (1997) Microsite effects on first-year establishment and overwinter survival of white spruce in aspen-dominated boreal mixedwoods. Canadian Journal of Forest Research, 27(9): 1452-1457. https://doi.org/10.1139/x97-109

DeMastus CR (2013) Effective methods of regenerating whitebark pine (Pinus albicaulis) through direct seeding. Montana State University, Bozeman, MT. MS Thesis. 126 p.

Densmore RV, Juday GP, Zasada JC (1999) Regeneration alternatives for upland white spruce after burning and logging in interior Alaska. Canadian journal of forest research, 29(4): 413-423. https://doi.org/10.1139/x99-008

Dey DC, Jacobs DF, McNabb K, Miller GW, Baldwin VC, Foster GS, Bridgwater F (2008) Artificial regeneration of major oak (Quercus) species in the eastern United States-a review of the literature. For Sci 54 (1): 77-106.

Dey DC, Buchanan M (1995) Red oak (Quercus rubra L.) acorn collection, nursery culture and direct seeding: a literature review. Ontario Ministry of Natural Resources, Ontario Forest Research Institute, Sault Ste. Marie, Ontario, Forest Research Information Paper 122: $46 \mathrm{p}$.

Dodd MB, Power IL (2007) Direct seeding of indigenous tree and shrub species into New Zealand hill country pasture. Ecol. Restor. Manage. 8: 49-55. https://doi.org/10.1111/i.14428903.2007.00332.x

Douglas GB, Dodd MB, Power IL (2007) Potential of direct seeding for establishing native plants into pastoral land in New Zealand. New Zealand Journal of Ecology 31: 143-153.

Doust SJ, Erskine PD, Lamb D (2006) Direct seeding to restore rainforest species: Microsite effects on the early establishment and growth of rainforest tree seedlings on degraded land in the wet tropics of Australia. For. Ecol. Manage. 234: 333-343. https://doi.org/10.1016/i.foreco.2006.07.014

Doust SJ, Erskine PD, Lamb D (2008) Restoring rainforest species by direct seeding: Tree seedling establishment and growth performance on degraded land in the wet tropics of Australia. For. Ecol. Manage. 256: 1178-1188. https://doi.org/10.1016/i.foreco.2008.06.019

du Cros ET, Bariteau M, Kramer K (2004) Long-term socio-ecological forest research in southeast France. Forest Snow Landscape Research 78: 83-92.

Duryea ML (1985) Nursery cultural practices: impacts on seedling quality. In: Duryea ML, Landis TD (eds) Forest nursery manual: production of bareroot seedlings. Martinus Nijhoff/Dr. W. Junk Publishers, The Hague, The Netherlands 143-164.

Duryea ML (1992) Forest regeneration methods: natural regeneration, direct seeding and planting. Circ. 759. Gainesville, FL: University of Florida, Florida Cooperative Extension Service, Institute of Food and Agricultural Sciences, School of Forest Resources and Conservation Department. 13 p.

Elliott S (2016) The potential for automating assisted natural regeneration of tropical forest Ecosystems. Biotropica 48(6): 825-833. https://doi.org/10.1111/btp.12387

Engel VL, Parrotta JA (2001) An evaluation of direct seeding for reforestation of degraded lands in central Sao Paulo state, Brazil. For. Ecol. Manage.

Erefur C, Bergsten U, de Chantal M (2008) Establishment of direct seeded seedlings of Norway spruce and Scots pine: effects of stand conditions, orientation and distance with respect to shelter tree, and fertilisation. Forest Ecology and Management, 255(3): 1186-1195. https://doi.org/10.1016/i.foreco.2007.10.024

Ersson BT (2014) Concepts for mechanized tree planting in southern Sweden. Diss. (sammanfattning/summary) Umeå : Sveriges lantbruksuniv., Acta Universitatis agriculturae Sueciae, 1652-6880; 2014:76. 
Ezell AW (2012) Direct seeding: a forest regeneration alternative. Pub. 1588. Starkville, MS: Mississippi State University, Department of Forestry. http://msucares.com/pubs/publications/p1588.htm

FAO (2015) Global forest resources assessment 2015: how are the world's forests changing? Food and Agriculture Organization of the United Nations. Rome, Italy. http://www.fao.org/3/a-i4793e.pdf

Farlee LD (2013) Direct seeding of fine hardwood tree species. In: Van Sambeek, J.W.; Jackson, Elizabeth A.; Coggeshall, Mark V.; Thomas, Andrew L.; Michler, Charles H. eds. 2013. Managing fine hardwoods after a half century of research: Proceedings of the Seventh Walnut Council Research Symposium; 2011 August 1-3; Madison, WI. Gen. Tech. Rep. NRS-P-115. Newtown Square, PA; U.S. Department of Agriculture, Forest Service, Northern Research Station: 31-47.

Farrelly N, Keane M, Ni Dhubhain A (2003) An Analysis of the effect of shelterwood, seeding density and scarification on the regeneration of Sitka spruce on a forest site in Co Wicklow. Irish Forestry, 60 (1-2):11-19.

Fields-Johnson C, Burger J, Evans D, Zipper C (2010) Response of improved American chestnuts to planting practices on reclaimed surface mined land. In: Barnhisel, R.I., ed. Proc., 27th meeting, American Society of Mining and Reclamation. Pittsburgh, PA: American Society of Mining and Reclamation: 319-336.

Fima RG (2003) Airborne seed pouch delivery system. US Patent No.: US 6,516,565 B1

Finnish Statistical Yearbook of Forestry (2014) Downloaded from http://stat.luke.fi/sites/default/files/vsk14 koko julkaisu.pdf at 11. 15.2016. ISBN 978-951-402505-1 (PDF)

Fischer H, Huth F, Hagemann U, Wagner S (2016) Developing restoration strategies for temperate forests using natural regeneration processes. In:Stanturf JA (ed). Restoration of Boreal and Temperate Forests, $2^{\text {nd }}$ Edition. CRC Press, Boca Raton FL:103-164.

Fleming R, Groot A, Adams M, Van Damme L, Foreman F (2001) Direct Seeding. In In: Regenerating Ontario's Forests. Wagner B Colombo SJ (eds) Fitzhenry and Whiteside Ltd., Markham, Ont: 351373.

Fleming RL, Mossa DS (1989) Direct seeding of black spruce. ON Min. Nat. Res. NW ON Tech Dev Unit On Line 2(3): 1-2.

Fleming RL, Mossa DS (1994) Direct seeding of black spruce in northwestern Ontario: seedbed relationships. The Forestry Chronicle, 70(2): 151-158. https://doi.org/10.5558/tfc70151-2

Fleming RL, Mossa, DS (1995) Direct seeding of black spruce in northwestern Ontario: temporal changes in seedbed coverage and receptivity. The Forestry Chronicle 71(2): 219-227. https://doi.org/10.5558/tfc71219-2

Florentine SK, Graz FP, Ambrose G, O'brien L (2013) The current status of different age, direct-seeded revegetation sites in an agricultural landscape in the burrumbeet Region, Victoria, Australia. Land Degradation and Development, 24(1): 81-89. https://doi.org/10.1002/ldr.1110

Foreman FF (1997) Aerial broadcast seeding jack pine on burns (Data Reported In: Fleming R, Groot A, Adams M, Van Damme L, Foreman F (2001) Direct Seeding. In: Regenerating Ontario's Forests. Wagner B Colombo SJ (eds) Fitzhenry and Whiteside Ltd., Markham, Ont: 351-373.

Forest Genetics Council of BC (2016) Annual Report 2015-2016: 13p.

Forestry Directorate (2016) Funding regulations - http://www.upravazasume.gov.rs/wpcontent/uploads/2016/10/III-Konkurs-za-fond-2016-u-2016-godini-po-izmeni-Uredbe.doc

Fraser JW (1981) Operational direct seeding trials with black spruce on upland cutovers. Dep. Environ., Can. For. Serv., Sauh Ste. Marie, ON. Inf. Rep. O-X-321. 34 p.

Frochot H, Balandier P, Sourisseau A (2009) Seed Dormancy and Consequences for Direct Tree Seeding. Forest Vegetation Management-Towards Environmental Sustainability from the Final COST E47 Conference, (ed. NS Bentsen), May 5-7, Vejle, Forest and Landscape Working Papers, 35: 43-45.

García Cuevas X, Velasco Bautista E, Rodríguez Santiago B, González Hernández A, Camacho Morfín F (2010) Evaluación de la siembra aérea con Enterolobium cyclocarpum (Jacq.) Griseb en el ejido Leona Vicario, Quintana Roo. Revista mexicana de ciencias forestales, 1(2): 109-119.

García-Orth X, Martínez-Ramos M (2008) Seed dynamics of early and late successional tree species in tropical abandoned pastures: seed burial as a way of evading predation. Restoration Ecology, 16: 435-443. https://doi.org/10.1111/i.1526-100X.2007.00320.x 
Gauthier MM, Ruel JC (2008) Enrichment of natural regeneration through direct seeding and fill planting in logging trails of black spruce stands. Tree Planters' Notes 52(2):18-23.

Gjerstad DH, Nelson LR, Dukes JH, Ratzlaff SA (1984) Growth response and physiology of tree species as affected by weed control. In: Seedling physiology and reforestation success. Edited by M.L. Duryea and G.N. Brown. Martinus Nijhoff / Dr. W. Junk Publishers, Dorchrecht, The Netherlands: 247-257. https://doi.org/10.1007/978-94-009-6137-1 11

Gladstone WT, Ledig FT (1990) Reducing pressure on natural forests through high-yield forestry. For. Ecol. Manage. 35: 69-78. https://doi.org/10.1016/0378-1127(90)90232-Z

González-Rodríguez V, Navarro-Cerrillo RM, Villar R (2011) Artificial regeneration with Quercus ilex L. and Quercus suber L. by direct seeding and planting in southern Spain. Annals of Forest Science 68: 637p. https://doi.org/10.1007/s13595-011-0057-3

Grabau MR, Milczarek MA, Karpiscak MM, Raulston B (2011) Direct seeding for riparian tree re-vegetation: small-scale field study of seeding methods and irrigation techniques. Ecol. Eng. 37: 864-872. https://doi.org/10.1016/i.ecoleng.2011.01.003

Groot A (1988) Methods for estimating seedbed receptivity and for predicting seedling stocking and density in broadcast seeding. Can J For Res 18: 1541-1549. https://doi.org/10.1139/x88-236

Groot A (1994) Key considerations to ensure desired stocking in broadcast seeding. Can For Serv. Tech. Note No. 45.

Groot A (1996) Direct seeding black spruce on peatlands: tenth year results. Can. For. Serv., Sault Ste. Marie, ON NODA/NFP Tech. Rep. TR-27.

Groot A, Adams MJ (1994) Direct seeding black spruce on peatlands: fifth-year results. For. Chron. 70 : 585-592. https://doi.org/10.5558/tfc70585-5

Grossnickle SC (2000) Ecophysiology of northern spruce species: the performance of planted seedlings. NRC Research Press

Grossnickle SC (2005) Importance of root growth in overcoming planting stress. New For 30: $273-294$. https://doi.org/10.1007/s11056-004-8303-2

Grossnickle SC (2012) Why seedlings survive: Importance of plant attributes. New For 43: 711-738. https://doi.org/10.1007/s11056-012-9336-6

Grossnickle SC, MacDonald J (2017) Why seedlings grow: Importance of plant attributes. New For https://doi.org/10.1007/s1056-017-9606-4

Grossnickle SC, YA El-Kassaby (2016) Bareroot versus container stocktypes: a performance comparison. New For 47: 1-51. https://doi.org/10.1007/s11056-015-9476-6

Halmer P (2006) Seed technology and seed enhancement. In XXVII International Horticultural CongressIHC2006: International Symposium on Seed Enhancement and Seedling Production 771: 17-26.

Halter MR, Chanway CP, Harper GJ (1993) Growth reduction and root deformation of containerized lodgepole pine saplings 11 years after planting. For. Ecol. Manage. 56: 131-146. https://doi.org/10.1016/0378-1127(93)90108-Y

Hanssen KH (2002) Effects of seedbed substrates on regeneration of Picea abies from seeds. Scand. J. For. Res. 17: 511-521. https://doi.org/10.1080/02827580260417161

Harlow WH, Harrar ES (1969) Textbok of dendrology: covering the important forest tree species of the United States and Canada. McGraw-Hill NY

Harrington CA, Brissett JC, Carlson WC (1989) Root system structure in planted and seeded loblolly pine and shortleaf pine. For Sci 35: 469-480.

Haywood JD, Barnett JP (1994) Comparing methods of artificially regenerating loblolly and slash pines: container planting, bareroot planting, and spot seeding. Tree Planters' Notes 45(2): 63-67.

Helenius P (2016) Direct Seeding of Scots Pine is a Popular Forest Regeneration Method in Finland. Tree Seed Working Group News Bulletin, Canadian Forest Genetics Association, 64: 8-11.

Herman RK (1978) Seeding. In: Cleary BD, Greaves RD, Hermann RK (eds) Regenerating Oregon's Forests: a guide for the regeneration forester. OR Sta Univ Ext Serv, Corvallis, OR: 148-162.

Hewitt N, Kellman M (2004) Factors influencing tree colonization in fragmented forests: an experimental study of introduced seeds and seedlings. For Ecol Manage 191: 39-59. https://doi.org/10.1016/j.foreco.2003.11.003 
Hille M, den Ouden (2004) Improved recruitment and early growth of Scots pine (Pinus sylvestris L.) seedlings after fire and soil scarification J. Eur J Forest Res (2004) 123: 213 p.

Holl KD, Loik ME, Lin EHV (2000) Tropical montane forest restoration in Costa Rica: overcoming barriers to dispersal and establishment. Restor Ecol 8: 339-349. https://doi.org/10.1046/j.1526100x.2000.80049.x

Holl KD, Aide TM (2011) When and where to actively restore ecosystems? Forest Ecology and Management 261(10): 1558-1563. https://doi.org/10.1016/i.foreco.2010.07.004

Holmström E, Hjelm K, Karlsson M, Nilsson U (2016) Scenario analysis of planting density and precommercial thinning: will the mixed forest have a chance? Eur J Forest Res 135: 885p. https://doi.org/10.1007/s10342-016-0981-8

Hooper E, Condit R, Legendre P (2002) Response of 20 native tree species to reforestation strategies for abandon farmlands in Panama. Ecol Appl, 12: 1626-1641. https://doi.org/10.1890/10510761(2002)012[1626:RONTST]2.0.CO;2

Hossain F, Elliott S, Chairuangsri S (2014) Effectiveness of Direct Seeding for Forest Restoration on Severely Degraded Land in Lampang Province, Thailand. Open Journal of Forestry, 4: 512-519. https://doi.org/10.4236/ojf.2014.45055

Howlett BE, Davidson DW (2003) Effects of seed availability, site conditions, and herbivory on pioneer recruitment after logging in Sabah, Malaysia. For Ecol Manage 184: 369-383. https://doi.org/10.1016/S0378-1127(03)00161-0

Huebschmann MM, Wittwer RF (1992) Comparison of Seeding Versus Planting Loblolly Pine in Rips. Tree Planters' Notes 43(2): 48-51.

Ivetić V, Devetaković J, Nonić M, Stanković D, Šijačić-Nikolić M (2016) Genetic diversity and forest reproductive material - from seed source selection to planting. iForest 9: 801-812. https://doi.org/10.3832/ifor1577-009

Ivetić V, Devetaković J (2016) Reforestation challenges in Southeast Europe facing climate change. Reforesta 1: 178-220. https://doi.org/10.21750/10.21750/REFOR.1.10.10

Ivetić V, Devetaković J (2017) Concerns and evidence on genetic diversity in planted forests. Reforesta 3 : 196-207. https://doi.org/10.21750/REFOR.3.15.39

Ivkov R (1971) Forest cultures and plantations - establishing and silviculture. $2^{\text {nd }}$ edition. Naučna knjiga, Beograd. [In Serbian].

James A (1990) Invasion of woody species was heavily dominated by light-seeded species, and was highest in stands close to mature trees. South. J. Appl. For. 14(4): 206-210.

Jinks RL, Parratt M, Morgan G (2012) Preference of granivorous rodents for seeds of 12 temperate tree and shrub species used in direct sowing. Forest Ecology and Management, 278: 71-79. https://doi.org/10.1016/i.foreco.2012.05.013

Jinks RL, Willoughby I, Baker C (2006) Direct seeding of ash (Fraxinus excelsior L.) and sycamore (Acer pseudoplatanus L.): The effects of sowing date, pre-emergent herbicides, cultivation, and protection on seedling emergence and survival. For. Ecol. Manage. 237: 373-386. https://doi.org/10.1016/j.foreco.2006.09.060

Jõgiste K, Metslaid M, Uri V (2016) Afforestation and land use dynamics in the Baltic States. In: Stanturf JA (ed). Restoration of Boreal and Temperate Forests, $2^{\text {nd }}$ Edition. CRC Press, Boca Raton FL, 187 199.

Johnson RL, Krinard RM (1985) Regeneration of oaks by direct seeding. In: Proceedings, Third Symposiun of Southeastern Hardwoods; 1985 April 16-17; Dothan, AL. Atlanta, GA: U.S. Department of Agriculture, Forest Service, Southern Region; 1985: 56-65. In cooperation with: Alabama: Forestry Comnission, the Mississippi Forestry Commission and the Alabama Extension Service.

Kankaanhuhta V, Saksa T (2013) Cost-quality relationship of Norway spruce planting and Scots pine direct seeding in privately owned forests in southern Finland. Scand. J For. Res. 28: 481-492. https://doi.org/10.1080/02827581.2013.773065

Kankaanhuhta V, Saksa T, Smolander H (2009) Variation in the results of Norway spruce planting and Scots pine direct seeding in privately-owned forests in southern Finland. Silva Fen. 43: 51-70. https://doi.org/10.14214/sf.217 
Khurana E, Singh JS (2001) Ecology of tree seed and seedlings: implication for tropical forest Conservation and restoration. Current Science 80: 748-757.

Kjelgren R (1994) Growth and water relations of Kentucky coffee tree in protective shelters during establishment. HortScience 29(7): 777-780.

Knight AJP, Beale PE, Dalton GS (1997) Direct seeding of native trees and shrubs in low rainfall areas and on non-wetting sands in South Australia. Agrofor. Sys. 39: 225p.

Koch JM, Samsa GP (2007) Restoring Jarrah forest trees after bauxite mining in Western Australia. Restoration Ecology 15 (Supplement): S17-S25. https://doi.org/10.1111/j.1526100X.2007.00289.x

Laborde J, Corrales-Ferrayola I (2012) Direct seeding of Brosimum alicastrum Sw. (Moraceae) and Enterolobium cyclocarpum (Jacq.) Griseb. (Mimosaceae) in different habitats in the dry tropics of central Veracruz. Acta botánica mexicana 100: 107-134. https://doi.org/10.21829/abm100.2012.33

Laliberté E, Cogliastro A, Bouchard A (2008) Spatiotemporal patterns in seedling emergence and early growth of two oak species direct-seeded on abandoned pastureland. Annals of Forest Science 65(4): 1. https://doi.org/10.1051/forest:2008019

Laman TG (1995) Ficus Stupenda germination and seedling establishment in a bornean rain forest canopy. Ecology 76: 2617-2626. https://doi.org/10.2307/2265832

Lamb D, Erskine PD, Parrotta JA (2005) Restoration of degraded tropical forest landscapes. Science 310(5754): 1628-1632. https://doi.org/10.1126/science.1111773

Landis TD, Tinus RW, Barnett JP (1998) Seedling propagation. The container tree nursery manual. Vol. 6. USDA For Serv Agric Handb 674, Washington, DC

Lawrence WH, Rediske JH (1962) "Fate of sown Douglas-fir seed." Forest Science 8: 210-218.

Ledgard N, Charru M, Davey H (2008) Establishing native species from seed within exotic grasslands. New Zealand Journal of Forestry 53: 23-32.

Ledgard N, Davis M (2004) Restoration of mountain beech (Nothofagus solandri var. cliffortioides) forest after fire. New Zealand Journal of Ecology 28: 125-135.

Ledgard NJ (1976) Research into the direct seeding of woody plants in high country revegetation. New Zealand Journal of Forestry 21: 253-264.

Lee S, Thompson D, Hansen JK, (2013) Forest Tree Breeding in Europe, L. E. Paques, ed., vol. 25 of Managing Forest Ecosystems, Springer Netherlands, 177-227. https://doi.org/10.1007/978-94007-6146-9 4

Leinonen T, Sungurov R, Kolstrom T, Sokolov A, Zigunov A, Dorosin A (2008) Forest regeneration in Northern and Northwestern Russia in 1993-2004-methods, results and development needs For. Ecol. Manag. 255: 383-395. https://doi.org/10.1016/i.foreco.2007.10.044

Leverkus AB, Castro J, Puerta-Piñero C, Rey Benayas JM (2013) Suitability of the management of habitat complexity, acorn burial depth, and a chemical repellent for post-fire reforestation of oaks. Ecol Eng 53:15-22. https://doi.org/10.1016/i.ecoleng.2013.01.003

Li Q, Ma K (2003) Factors affecting establishment of Quercus liaotungensis Koidz. Under mature mixed oak forest overstory and in shrubland. For. Ecol. Manage. 178: 133-146. https://doi.org/10.1016/S0378-1127(02)00274-8

Li G, Liu Y, Ma L, Lv R, Yu H, Bai S, Kang Y (2009) Comparison of tree growth and undergrowth development in aerially seeded and planted Pinus tabulaeformis forests. Front. For. China (2009) 4: 283. https://doi.org/10.1007/s11461-009-0049-8

Lindgren D (2016) The role of tree breeding in reforestation. Reforesta 1: 221-237. https://doi.org/10.21750/REFOR.1.11.11

Little S, Somes HA (1964) Root systems of direct-seeded and variously planted loblolly, shortleaf, and pitch pines. USDA For. Serv. RES Pap. NE-26

Lockhart BR, Keeland B, McCoy J, Dean TJ (2003) Comparing regeneration techniques for afforesting previously farmed bottomland hardwood sites in the Lower Mississippi Alluvial Valley, USA. Forestry 76: 169-180. https://doi.org/10.1093/forestry/76.2.169 
Loewenstein H, Pitkin F (1966) A direct seeding experiment with four tree species native to northern Idaho. Sta. Note No. 3. Moscow, ID: University of Idaho Forestry, Wildlife, and Range Experiment Station: 4 p.

Löf M, Birkedal M (2009) Direct seeding of Quercus robur L. for reforestation: The influence of mechanical site preparation and sowing date on early growth of seedlings. For Ecol Manage 258: 704-711. https://doi.org/10.1016/j.foreco.2009.05.008

Löf M, Thomsen A, Madsen P. (2004) Sowing and transplanting of broadleaves (Fagus sylvatica L., Quercus robur L., Prunus avium L. and Crataegus monogyna Jacq.) for afforestation of farmland. For Ecol Manage 188: 113-123. https://doi.org/10.1016/j.foreco.2003.07.013

Löf M, Welander NT (2004) Influence of herbaceous competitors on early growth in direct seeded Fagus sylvatica L. and Quercus robur L. Ann For Sci 61: 781-788. https://doi.org/10.1051/forest:2004075

Long JN (1978) Root system form and its relationship to growth in young planted conifers. In: Van Eerden E, Kinghorn JM (eds) Proceedings, root form of planted trees symposium. BC Ministry of Forest/ Canadian Forest Services, Victoria, BC, Jt rep 8: 222-234.

Madsen P, Jensen FA, Fogaard S (2016) Afforestation in Denmark. In: Stanturf JA (ed). Restoration of Boreal and Temperate Forests, $2^{\text {nd }}$ Edition. CRC Press, Boca Raton FL, pp 201-216

Madsen P, Löf M (2005) Reforestation in southern Scandinavia using direct seeding of oak (Quercus robur L.) Forestry 78 (1). https://doi.org/10.1093/forestry/cpi005

Madsen MD, Davies KW, Boyd CS, Kerby JD, Svejcar TJ (2016) Emerging seed enhancement technologies for overcoming barriers to restoration. Restoration Ecology, 24(S2). https://doi.org/10.1111/rec.12332

Margolis HA, Brand DG (1990) An ecophysiological basis for understanding plantation establishment. Can J For Res 20: 375-390. https://doi.org/10.1139/x90-056

Matute P, Mitchell J (2015) Direct seeding in western Canada: A reforestation alternative? www.fpinnovations.ca

McKay HM (1997) A review of the effects of stresses between lifting and planting on nursery stock quality and performance. New For 13: 369-399. https://doi.org/10.1023/A:1006563130976

Mendoza I, Zamora R, Castro J (2009) A seeding experiment for testing tree-community recruitment under variable environments: implications for forest regeneration and conservation in Mediterranean habitats. Biological conservation, 142(7): 1491-1499. https://doi.org/10.1016/i.biocon.2009.02.018

Miller LK, DeBell J. (2013) Current seed orchard techniques and innovations. In: Haase DL, Pinto JR, Wilkinson KM, technical coordinators. National Proceedings: Forest and Conservation Nursery Associations-2012. Fort Collins (CO): USDA Forest Service, Rocky Mountain Research Station. Proceedings RMRS-P-69. 80-86. Available at: http:// www.fs.fed.us/rm/pubs/rmrs p069.html

Minnemeyer S, Laestadius L, Sizer N, Saint-Laurent C, Potapov P (2011) A world of opportunity. World Resources Institute, Washington, DC.

Mitchell WK, Dunsworth G, Simpson DG, Vyse A (1991) Planting and Seeding. In: Lavender DP, Parish R, Johnson CM, Montgomery G, Vyse A, Willis RA, Winston D (eds) (1990) Regenerating British Columbia's forests. Univ BC Press, Vancouver, BC. 236-253.

Morris MH, Negreros-Castillo P, Mize C (2000) Sowing date, shade, and irrigation affect big-leaf mahogany (Swietenia macrophylla King). Forest Ecology and Management, 132(2): 173-181. https://doi.org/10.1016/S0378-1127(99)00224-8

Motsinger JR, Kabrick JM, Dey DC, Henderson DE, Zenner EK (2010) Effect of midstory and understory removal on the establishment and development of natural and artificial pin oak advance reproduction in bottomland forests. New For 39: 195-213. https://doi.org/10.1007/s11056-0099164-5

Moulton RJ (1999) Tree Planting in the United States---1997. Tree Planter's Notes, 49 (1).

Mullins JA, Buckner ER, Hopper G, Percell G (1997) Early growth of sheltered and unsheltered cherrybark oak established by planting 1-0 bareroot and 1-0 containerized seedlings, and by direct seeding. Pages 234-237 in Proceedings of the Ninth Biennial Southern Silvicultural Research Conference, 
Clemson, South Carolina, February 25-27, 1997. General Technical Report SRS-20. USDA Forest Service, Southern Research Station, Asheville, North Carolina.

Natural Resources Canada (2014) The State of Canada's Forests: Annual Report 2014. ISSN 1488-2736. $72 \mathrm{p}$.

National Resources Conservation Services (2015) Direct Seeding of Tree \& Shrubs. USDA Forestry Tech Note Number 16. 4pp.

Negreros-Castillo P, Snook LK, Mize CW (2003) Regenerating mahogany (Swietenia macrophylla) from seed in Quintana Roo, Mexico: the effects of sowing method and clearing treatment. Forest Ecology and Management, 183(1): 351-362. https://doi.org/10.1016/S0378-1127(03)00143-9

Nichols TJ, Alm AA (1983) Root development of container-reared, nursery grown, and naturally regenerated pine seedlings. Can. J. For. Res. 13: 239-245. https://doi.org/10.1139/x83-033

Nilson ME, Hjältén J (2003) Covering pine-seeds immediately after seeding: effects on seedling emergence and on mortality through seed-predation. Forest Ecology and Management, 176(1): 449-457. https://doi.org/10.1016/S0378-1127(02)00308-0

Nilsson U, Gemmel P, Löf M, Welander T, (1996) Germination and early growth of sown Quercus robur L. in relation to soil preparation, sowing depths and prevention against predation. New Forests 12: 69-86. https://doi.org/10.1007/BF00029983

Noble BF (1985) Comparative costs and survival rates of direct seeding, germinant and seedling plantings of denuded Benguet pine (Pinus kesiya Royle ex Gordon) areas. Sylvatrop. The Philippines Forest Research Journal, 10(4): 259-270.

Nolte DL, Barnett JP (2000) A repellent to reduce mouse damage to longleaf pine seed. International Biodeterioration and Biodegradation. 45: 169-174. https://doi.org/10.1016/S09648305(00)00060-3

Ochsner P (2001) Direct seeding in the tropics. Danida Forest seed Centre.

Oleskog G, Sahlén K (2000) Effects of seedbed substrate on moisture conditions and germination of Scots pine (Pinus sylvestris) seeds in a mixed conifer stand. New Forests, 20(2): 119-133. https://doi.org/10.1023/A:1006783900412

Oliet JA, Vázquez de Castro A, Puértolas J (2015) Establishing Quercus ilex under Mediterranean dry conditions: sowing recalcitrant acorns versus planting seedlings at different depths and tube shelter light transmissions. New Forests 46: 869. https://doi.org/10.1007/s11056-015-9495-3

Oliver CD, O'Hara KL, Baker PJ (2016) Effects of restoration at the stand level. In: Stanturf JA (ed). Restoration of Boreal and Temperate Forests, $2^{\text {nd }}$ Edition. CRC Press, Boca Raton FL, 37-68.

Ortolani MR, Schirone A, Camillotti G, Schirone B (2015) Aerial reforestation by seed bombs. In: Ivetić V, Stanković D. (eds.) Proceedings: International Conference Reforestation Challenges. 03-06 June 2015, Belgrade, Serbia. Reforesta, 227-233.

Owston PW, Walters GA, Molina R (1992) Selection of planting stock, inoculation with mycorrhizal fungi, and use of direct seeding. In: Hobbs SD, Tesch SD, Owston PW, Stewart RE, Tappeiner II JC, Wells GE (eds) Reforestation practice in southwestern Oregon and northern California. For. Res. Lab. Oregon State Univ. 310-327.

Ozalp M, Schoenholtz SH, Hodges JD, Miwa M (1998) Influence of soil series and planting methods on fifth-year survival and growth of bottomland oak re-establishment in a farmed wetland. In Proceedings of the Ninth Biennial Southern Silvicultural Research Conference, T.A. Waldrop (ed.). US Dept. of Agriculture, Forest Service General Technical Report SRS-20. Southern Research Station, Asheville, NC, 277-283.

Madsen P, Bentsen NS, Madsen TL, Olesen CR (2006) Artificial beech regeneration in Denmark development of direct seeding and planting methods. In book of abstracts from IUFRO conference Beech silviculture in Europe's largest beech country. 4 - 8 September 2006, Poiana Brasov, Romania. 64-66. (In press at University of Brasov, Faculty of silviculture and forest engineering)

Palmerlee AP, Young TP (2010) Direct seeding is more cost effective than container stock across ten woody species in California. Native Plants J 11(2):89-102. https://doi.org/10.2979/NPJ.2010.11.2.89 
Pamela AC, Laurence SGW (2015) A review of direct seeding and seedling plantings in restoration: what do we know and where should we go. Appl. Veg. Sci. 18: 561-568. https://doi.org/10.1111/avsc.12173

Pandey DN, Prakash NP (2014) "Tropical Dry Forest Restoration: Science and Practice of Direct Seeding in a Nutshell". RSPCB Occasional Paper 7.

Parke EL, Linderman, RG, Black CH (1983) The role of ectomycorrhizas in drought tolerance of Douglas-fir seedlings. New Phytol. 95: 83-95. https://doi.org/10.1111/i.1469-8137.1983.tb03471.x

Parker WC, Dey DC, Newmaster SG, Elliott KA, Boysen E (2001) Managing succession in conifer plantations: converting young red pine (Pinus resinosa Ait.) plantations to native forest types by thinning and underplanting. The Forestry Chronicle, 77(4): 721-734. https://doi.org/10.5558/tfc77721-4

Parrotta JA, Knowles OH (1999) Restoration of Tropical Moist Forests on Bauxite-Mined Lands in the Brazilian Amazon. Restoration ecology 7(2): 103-116. https://doi.org/10.1046/i.1526100X.1999.72001.x

Parrotta JA, Knowles OH (2001) Restoring tropical forests on lands mined for bauxite: examples from the Brazilian Amazon. Ecological Engineering 17(2): 219-239. https://doi.org/10.1016/S0925$\underline{8574(00) 00141-5}$

Pausas JG, Bladé C, Valdecantos A, Seva JP, Fuentes D, Alloza JA, Vilagros, A, Bautista S, Cortina J, Vallejo (2004) Pines and oaks in the restoration of Mediterranean landscapes in Spain: New perspectives for an old practice - a review. Plant Ecology 171: 209-220. https://doi.org/10.1023/B:VEGE.0000029381.63336.20

Pemána J, Peguero-Pinab JJ, Valladaresc F, Gil-Pelegrínb E (2009) Evaluation of unventilated treeshelters in the context of Mediterranean climate: Insights from a study on Quercus faginea seedlings assessed with a 3D architectural plant model. Ecological Engineering 36: 517-526. https://doi.org/10.1016/j.ecoleng.2009.11.021

Peppin DL, Fule' PZ, Sieg CH, Beyers JL, Hunter ME (2010) Post-wildfire seeding in forests of the western United States: an evidence-based review. Forest Ecology and Management 260: 573-586. https://doi.org/10.1016/i.foreco.2010.06.004

Petursson JG, Sigurgeirsson A, (2004) Direct seeding of boreal conifers on freely drained andosols in Southern Iceland. Icelandic Agricultural Sciences 16/17: 15-28.

Piggott JP, Brown PH, Williams MM (1987) Direct seeding trees on farmland in the Western Australian wheatbelt. Department of Agriculture and Food, Western Australia. Report 146.

Preisig CL, Carlson WC, Promnitz LC (1979) Comparative root system morphologies of seed-in-place, bareroot, and containerized Douglas-fir seedlings after outplanting. Can J For Res 9: 399-405. https://doi.org/10.1139/x79-067

Radosevich SR, Osteryoung K (1987) Principles governing plant-environment interactions. In: Forest vegetation management for conifer production. Edited by J.D. Walstad and P.J. Kuch. John Wiley and Sons, New York. 105-156.

Ray GJ, Brown BJ (1995) Restoring Caribbean dry forests: evaluation of tree propagation techniques. Restoration ecology, 3(2): 86-94. https://doi.org/10.1111/j.1526-100X.1995.tb00081.x

Repáč I, Parobeková Z, Sendecký M (2017) Reforestation in Slovakia: History, current practice and perspectives. Reforesta 3: 53-88. https://doi.org/10.21750/REFOR.3.07.31

Reque JA, Martin E (2015) Designing acorn protection for direct seeding of Quercus species in high predation areas. Forest Systems 24 (1): e-018, 5 p.

Riley LE, Haase DL, Pinto JR (tech coords) Joint Meeting of the Western Forest and Conservation Nursery Association and Forest Nursery Association of British Columbia Target Seedling Symposium, National proc: forest and conservation nursery associations - 2010. USDA For Serv RMRS-P-65.

Riley LF (1973) Silviculture treatment of seeded stands. Pages 139-155 In J.H. Cayford, ed. Direect Seeding Symposium. Timmins, Ontario, 11-13 September 1973, Dept, Environ., Canadian Forestry Service. Ottawa, ON. 178 p.

Rose R, Haase DL (2006) Guide to Reforestation in Oregon. College of Forestry, Oregon State University, Corvallis. $48 p$. 
Rose R, Carlson WC, Morgan P (1990) The target seedling concept. In: Rose R, Campbell SJ, Landis TD (eds) Target seedling symposium: Proc: combined meeting of the Western forest nursery associations. USDA For Serv RM-GTR-200, 1-8.

Rouvinen S, Kouki J (2011) Tree regeneration in artificial canopy gaps established for restoring natural structural variability in a Scots pine stand. Silva Fennica 45(5): 1079-1091. https://doi.org/10.14214/sf.88

Ruiz-Jaen MC, Mitchell Aide T (2005) Restoration success: how is it being measured?. Restoration ecology, 13(3): 569-577. https://doi.org/10.1111/j.1526-100X.2005.00072.x

Rytter L, Ingerslev M, Kilpeläinen A, Torssonen P, Lazdina D, Löf M, Madsen P, Muiste P, Stener LG (2016) Increased forest biomass production in the Nordic and Baltic countries - a review on current and future opportunities. Silva Fennica 50 (5): article id 1660. 33 p.

Sampaio AB, Holl KD, Scariot A (2007) Does restoration enhance regeneration of seasonal deciduous forests in pastures in central Brazil? Restoration Ecology 15(3): 462-471. https://doi.org/10.1111/i.1526-100X.2007.00242.x

Sánchez-González M, Gea-Izquierdo G, Pulido F, Acácio V, McCreary D, Cañallas I (2016) Restoration of Open Oak Woodlands in Mediterranean Ecosystems of Western Iberia and California. In: Stanturf JA (ed). Restoration of Boreal and Temperate Forests, $2^{\text {nd }}$ Edition. CRC Press, Boca Raton FL, pp 377-399.

Schiechtl H (1980) Bioengineering for land reclamation and conservation. Univ. Alberta Press

Schmidt $L$ (2008) A review of direct sowing versus planting in tropical afforestation and land rehabilitation. Horsholm: Forest and Landscape Denmark; p. iv + 38 pp.

Schultz RP (1997) Loblolly pine: the ecology and culture of loblolly pine (Pinus taeda L.). Agriculture Handbook 713. Washington, D.C.: U.S. Department of Agriculture, Forest Service. 493 p.

Schweitzer CJ, Stanturf JA (1999) A Comparison of Large-Scale Reforestation Techniques Commonly Used on Abandoned Fields in the Lower Mississippi Alluvial Valley. Tenth Biennial Southern Silvicultural Research Conference, Shreveport, LA,136-141.

Schweitzer CJ, Stanturf JA, Shepard JP, Wilkins TM, Portwood CJ, Lamar JrC, Dorris J (1997) Large-scale comparison of reforestation techniques commonly used in the Lower Mississippi Alluvial Valley: First year results. 1lth Central Hardwood Forest Conference, 313-320.

Sharapov VF (1931) Instructions for private forests silviculture. Vol. 2. State Publishing, MoscowLeningrad. [In Russian].

Sheridan RA, Davis AS, Haase DL (2016) Mulching and Shade Effects on Emergence and Survival of DirectSeeded Western Redcedar (Thuja plicata). Tree Planters' Notes 59(1): 33-41.

Show SB (1924) Some results of experimental forest planting in northern California. Ecology 5(1): 83-94. https://doi.org/10.2307/1929167

Silva RR, Oliveira DR, da Rocha GP, Vieira DL (2015) Direct seeding of Brazilian savanna trees: effects of plant cover and fertilization on seedling establishment and growth. Restoration Ecology 23(4): 393-401. https://doi.org/10.1111/rec.12213

Silva RR, Vieira DLM (2017) Direct seeding of 16 Brazilian savanna trees: responses to seed burial, mulching and an invasive grass. Appl Veg Sci 20: 410-421. https://doi.org/10.1111/avsc.12305

Singh AN, Singh JS (2006) Experiments on ecological restoration of coal mine spoil using native trees in a dry tropical environment, India: a synthesis. New forests 31(1): 25-39. https://doi.org/10.1007/s11056-004-6795-4

Sloan S, Sayer JA (2015) Forest Resources Assessment of 2015 shows positive global trends but forest loss and degradation persist in poor tropical countries. Forest Ecology and Management 352: 134145. https://doi.org/10.1016/i.foreco.2015.06.013

Smith DM (1962) The Practice of Silviculture, $7^{\text {th }}$ Edition, John Wiley and Sons, New York

Smith WD, Strub MR (1991) Initial spacing: How many trees to plant. In: Duryea ML, Dougherty PM (eds) Forest Regeneration Manual. Kluwer Academic Publishers, Dordrecht, The Netherlands, 281-289. https://doi.org/10.1007/978-94-011-3800-0 15

Smith CM, Poll G, Miranda E, Hill J (2011) Limber pine seed and seedling planting experiment in Waterton Lakes National Park, Canada. USDA Forest Service. Proceedings RMRS-P-63. 
Smith JHG, Walters J, Haddock PG (1968) Planting Can Be Better Than Direct Seeding of Douglas-Fir. Journal of Forestry 66 (4):351-353.

Smreciu EA, Gould K (2015) Field emergence of native boreal forest species on reclaimed sites in northeastern Alberta. Native Plants Journal 16(3): 204-226. https://doi.org/10.3368/npj.16.3.204

So $\mathrm{T}$ (2011) Improving reforestation success of high-value and key forest species by direct seeding in Southeast Asia and Western Australia. PhD thesis, Murdoch University; 200 p.

Society for Ecological Restoration Science and Policy Working Group (SER) (2002) The SER primer on ecological restoration. http://www.ser.org/Primer.pdf

South DB, Starkey TE, Enebak SA (2016) Forest nursery practices in the Southern United States. Reforesta 1:106-146. https://doi.org/10.21750/REFOR.1.07.7

Sovu, Savadogo P, Tigabu M, Odén PC (2010) Restoration of former grazing lands in the highlands of Laos using direct seeding of four native tree species: seedling establishment and growth performance. Mt Res Dev 30: 232-243. https://doi.org/10.1659/MRD-JOURNAL-D-10-00031.1

Stamenković V, Vučković M, Stojakov B (1994) Austrian pine as the pioneer species in the Deliblato sand afforestation. In: Marinković P. Ed: the Deliblato sands - Proceedings VI, 1994, Pančevo, Serbia. [On Serbian with Abstract and Summary on English]. 343-352.

Stanturf JA (2016) Restoring boreal and temperate forests: a perspective. In: Stanturf JA (ed). Restoration of Boreal and Temperate Forests, $2^{\text {nd }}$ Edition. CRC Press, Boca Raton FL, 519-533.

Stanturf JA, Palik BJ, Dumroese RK (2014) Contemporary forest restoration: A review emphasizing function. For Ecol Manage 331: 292-323. https://doi.org/10.1016/j.foreco.2014.07.029

Stanturf JA, Kennedy HE (1996) Survival and growth of planted and direct-seeded cherrybark oak in South Carolina. Southern Journal of Applied Forestry 20(4): 194-196.

Stanturf JA, Gardiner ES, Shepard JP, Schweitzer CJ, Portwood CJ, Dorris LC (2009) Restoration of bottomland hardwood forests across a treatment intensity gradient. Forest ecology and management, 257(8): 1803-1814. https://doi.org/10.1016/j.foreco.2009.01.052

Stanturf JA, Schweitzer CJ, Gardiner ES (1998) Afforestation of marginal agricultural land in the Lower Mississippi River Alluvial Valley, U.S.A. Silva Fennica 32(3): 281-297. https://doi.org/10.14214/sf.688

St-Denis A, Messier C, Kneeshaw D (2013) "Seed Size, the Only Factor Positively Affecting Direct Seeding Success in an Abandoned Field in Quebec, Canada." Forests 4(2): 500-516. https://doi.org/10.3390/f4020500

Stevenson BA, Smale MC (2005) Seed bed treatment effects on vegetation and seedling establishment in a New Zealand pasture one year after seeding with native woody species. Ecol Manage Restor 6 : 124-131. https://doi.org/10.1111/j.1442-8903.2005.00229.x

Stewart JD, Landhäusser SM, Stadt KJ, Lieffers VJ (2000) Regeneration of white spruce under aspen canopies: seeding, planting, and site preparation. Western Journal of Applied Forestry 15(4): 177182.

Stiell WM (1959) Seeding and planting red and white pine. Canada Dep. Northern Affairs and National Resources, Tech. Note 80, 19 p.

Sullivan TP, Sullivan DS (1984) Operational Direct Seeding of Douglasfir and Lodgepole Pine with Alternative Foods in British Columbia. BC MoF Res Note No. 97, ISSN 0226-9368

Summers DM, Bryan BA, Nolan M, Hobbs TJ (2015) The costs of reforestation: a spatial model of the costs of establishing environmental and carbon plantings. Land Use Policy 44: 110-121. https://doi.org/10.1016/i.landusepol.2014.12.002

Sun D, Dickinson GR, Bragg AL (1995) Direct seeding of Alphitonia petriei (Rhamnaceae) for gully revegetation in tropical northern Australia. For. Ecol. Manage. 73: 249-257. https://doi.org/10.1016/0378-1127(94)03479-G

Sutton RF (1969) Form and development of conifer root systems. Commonw. Agric. Bur. Tech. Commun. No. 7. Commonwealth Forestry Bureau, Oxford, England.

Sutton RF (1985) Vegetation management in Canadian forestry. Inf. Rep. 0-X-369. Department of Environment, Canadian Forestry Service, Sault Ste. Marie, ON. 
Tabari M, Asri M (2008) Early growth of direct-seeded Quercus castaneifolia (C.A. Meter) Seedlings on different soils of Elm-Oak stands. J Biol Sci 8: 628-633. https://doi.org/10.3923/ibs.2008.628.633

The National Forestry Bureau (2013) China Forestry Development Report 2013; China Forestry Publishing House: Beijing, China, 2013. (In Chinese)

Thomson A (2007) Direct seeding: An option for British Columbia's north. FORREX Forest Research Extension Partnership, 7(1): Art. 21.

Toumey JW (1916) Seeding and planting. John Wiley and Sons, Inc. New York

Trencia J (1996) Influence of seed position on first-year survival and growth of directly seeded northern red oak. Tree Planter's Notes, 47: 68-75.

Trobaugh J (2012) Forest Seedling Planting in Washington State, Tree Planters' Notes, 55: 1-11.

Tunjai P, Elliott S (2011) Effects of seed traits on the success of direct seeding for restoring southern Thailand's lowland evergreen forest ecosystem. New For.

Twedt DJ, Wilson RR (2002) Development of oak plantations established for wildlife. For. Ecol. Manage. 162: 287-298. https://doi.org/10.1016/S0378-1127(01)00523-0

United Nations (2014) FORESTS Action Statements and Action Plans: The New York Declaration, www.unredd.org/portals/15/documents/ForestsDeclarationText.pdf

And www.un.org/climatechange/summit/wp-content/uploads/sites/2/2014/07/New-YorkDeclaration-on-Forest-\%E2\%80\%93-Action-Statement-and-Action-Plan.pdf.

Uriarte M, Chazdon RL (2016) Incorporating natural regeneration in forest landscape restoration in tropical regions: synthesis and key research gaps. Biotropica 48(6): 915-924. https://doi.org/10.1111/btp.12411

Valkonen S (2008) Survival and growth of planted and seeded oak (Quercus robur L.) seedlings with and without shelters on field afforestation sites in Finland. For. Ecol. Manage. 255:1085-1094. https://doi.org/10.1016/j.foreco.2007.10.038

Van Eerden E (1982) Root form of planted trees. In: Proceedings, Canadian Containerized Tree Seedling Symposium, September 14-16, 1981, Toronto, Ontario. Edited by J.B. Scarratt, C. Glerum, and C.A. Plexman. COJFRC Symp. Proc. O-P-10. Canadian Forestry Service, Great Lakes Forestry Center, Sault Ste. Marie, ON. 401-405.

Varmola M, Hyppönen M, Mäkitalo K, Mikkola K, Timonen M (2004) Forest Management and Regeneration Success in Protection Forests near the Timberline in Finnish Lapland, Scandinavian Journal of Forest Research 19(5): 424-441. https://doi.org/10.1080/02827580410030154

Vieira DL, Scariot A (2006) Principles of natural regeneration of tropical dry forests for restoration. Restoration Ecology, 14(1): 11-20. https://doi.org/10.1111/j.1526-100X.2006.00100.x

Villalobos A, Löf M, Schlyter F, Birgersson G, Olsson G, Witzell J (2017) Seed protection through predator's smell: Developing novel repellents to avoid granivorous Rodents. In Löf, M (Ed.). 2017. Program and Book of Abstracts of the IUFRO 3rd Restoring Forest: Regeneration and Ecosystem Function for the Future. Lund, Sweden 12-14 September 2017. Report 51. Swedish University of Agricultural Sciences, Southern Swedish Forest Research Centre, Alnarp. 23p.

Wagner RG, Zasada JC (1991) Integrating plant autoecology and silvicultural activities to prevent forest vegetation management problems. Forestry Chronicle 67: 506-513. https://doi.org/10.5558/tfc67506-5

Wahlenberg WG (1925) Reforestation by seed sowing in the northern Rocky Mountains. Journal of Agricultural Research. 30(7): 637-641.

Wakeley PC (1954) Planting the southern pines. USDA For Serv Agric Monogr No 18.

Waldron RM (1973) Direct seeding in Canada 1900-1972. - In Direct seeding symposium. Edited by J.H. Cayford. Dept. of Environment, Can. For. Ser. Pub. No. 1339: 11-27.

Wang J, Ren H, Yang L, Li D (2011) Factors influencing establishment by direct seeding of indigenous tree species in typical plantations and shrubland in South China. New For 42: 19-33. https://doi.org/10.1007/s11056-010-9234-8

Watson AJ, Tombleson JD (2002) Toppling in juvenile pines: a comparison of the root system characteristics of direct sown seedlings, and bare-root seedlings and cuttings. Plant and Soil 239: 187-196. https://doi.org/10.1023/A:1015036105630 
Wendel GW (1971) Converting hardwoods on poor sites to white pine by planting and direct seeding. Res. Pap. NE-188. Upper Darby, PA: U.S. Department of Agriculture, Forest Servcie, Northeastern Forest Experiment Station. 19 p.

Wennström U, Bergsten U, Nilsson JE (1999) Mechanized microsite preparation and direct seeding of Pinus sylvestris in boreal forests - a way to create desired spacing at low cost. New For. 18: 179198. https://doi.org/10.1023/A:1006506431344

Wennström U, Bergsten U, Nilsson JE (2007) Seedling establishment and growth after direct seeding with Pinus sylvestris: effects of seed type, seed origin, and seeding year. Silva Fenn. 41: 299-314. https://doi.org/10.14214/sf.298

West PW (2014) Growing Plantations, $2^{\text {nd }}$ Edition. Springer, New York. https://doi.org/10.1007/978-3319-01827-0

Williams HM, Burkeand VR, Craft MN (1999) The effects of seedling stock-type and direct-seeding on the early field survival of Nuttall oak planted on agricultural land. In: Landis, T.D.; Barnett, JR, tech. coords. National proceedings: forest and conservation nursery associations-1998. Gen. Tech. Rep. SRS-25. Asheville, NC: U.S. Department of Agriculture, Forest Service, Southern Research Station: 29-34.

Williams HM, Craft MN (1998) "First-year survival and growth of bareroot, container, and direct-seeded Nuttall oak planted on flood-prone agricultural fields". Faculty Publications. Paper 247. http://scholarworks.sfasu.edu/forestry/247

Willoughby I, Harrison A, Jinks R, Gosling P, Harmer R, Kerr G. (2007) The potential for direct seeding of birch on restock sites. Edinburgh: Forestry Commission; Information Note FCIN084.

Willoughby I, Jinks RL, Kerr G, Gosling PG (2004) Factors affecting the success of direct seeding for lowland afforestation in the UK. Forestry 77: 467-482. https://doi.org/10.1093/forestry/77.5.467

Willoughby I, Jinks RL (2009) The effect of duration of vegetation management on broadleaved woodland creation by direct seeding. Forestry 82 (3): 343-359. https://doi.org/10.1093/forestry/cpp012

Willoughby I, Clay D, Dixon F (2003) The effect of pre-emergent herbicides on germination and early growth of broadleaved species used for direct seeding. Forestry 76(1): 83-94. https://doi.org/10.1093/forestry/76.1.83

Winsa H, Bergsten U (1994) Direct seeding of Pinus sylvestris using microsite preparation and invigorated seed lots of different quality: 2-year results. Canadian Journal of Forest Research 24: 77-86. https://doi.org/10.1139/x94-012

Wittwer RF (1991) Direct seeding of bottomland oaks in Oklahoma. South J Appl For 15: 17-22.

Wood AD (1984) Developing a seed-containing dart and aerial delivery system for forestry applications. For. Chron. 60: 86-92. https://doi.org/10.5558/tfc60086-2

Wood AD (2000) Experimental studies of potential improvements in the forest regeneration capabilities of "seed-containing aerial darts". For. Chron. 76: 406-418. https://doi.org/10.5558/tfc76406-3

Woodall GS, Robinson CJ (2002) Direct seeding Acacias of different form and function as hosts for Sandalwood (Santalum spicatum (R. Br.) A. DC). Conservation Science Western Australia 4 (3): 130-134.

Woods K, Elliot S (2004) Direct seeding for forest restoration on abandoned agricultural land in northern Thailand. J Trop. For. Sci. 16: 248-259.

Xiao X, Wei X, Liu Y, Ouyang X, Li Q, Ning J. (2015) Aerial Seeding: An Effective Forest Restoration Method in Highly Degraded Forest Landscapes of Sub-Tropic Regions. Forests 2015; 6(6): 1748-1762. https://doi.org/10.3390/f6061748

Zaczek JJ, Steiner KC, Bowersox TW (1997) Northern red oak planting stock: 6-year results. New Forests 13(1): 177-191. https://doi.org/10.1023/A:1006578007777

Zhigunov A, Saksa T, Sved J (2014) Establishment of forest plantations with container tree seedlings. St. Petersburg Forest Technical University, St. Petersburg. 44 p. https://doi.org/10.1046/i.1526100x.2000.80050.x

Zimmerman JK, Pascarella JB, Aide TM (2000) Barriers to forest regeneration in an abandoned pasture in Puerto Rico. Restoration ecology 8(4): 350-360. 